\title{
INOVATÍVNE PRÍSTUPY V MAPOVANÍ A POSUDZOVANÍ ŠTRUKTÚRY A TEXTÚRY SPOLOČENSTIEV A PORASTOV V HORSKÝCH LESOCH NÍZKYCH TATIER
}

\author{
Jozef Vladovič, Tomáš Bucha \\ Národné lesnícke centrum - Lesnícky výskumný ústav Zvolen, T. G. Masaryka 22, SK - 96092 Zvolen, \\ e-mail:vladovic@nlcsk.org,bucha@nlcsk.org
}

VLAdOvič, J., BuCHA, T., 2013: Innovative approaches in mapping and assessing the structure and texture of mountain forest stands in Low Tatras. Lesnícky časopis - Forestry Journal, 59(1): 19-37, 2013, 16 fig., tab. 1, ref. 22, ISSN 0323 - 1046. Original paper.

The work addresses the thematic mapping and assessments of the forest stand structures based on a combination of remote sensing and terrestrial methods using geographic information systems (GIS). Building on our previous research, we present the results on thematic mapping of the sets of stand types in the model area Lomnistá Valley in the Low Tatras (1 $623 \mathrm{ha})$, structural types and elements, classification of structure and ecological stability of mountain forests in the localities Konštiaky, Široký úplaz, Martalúzka - Byčiarky in the Low Tatras covering 270 ha. In the locality Medvedia úboč in Lomnistá Valley with the communities of natural forests in the fir-beach altitudinal vegetation zone, the innovative methods of thematic mapping of stand structure types and segments, based on RS, GIS, segmentation methods and mobile technologies, are presented. Stand texture types, elements and segments were identified, localized and partially classified on orthorectified digital multispectral aerial scenes combined with SPOT satellite scene. Historical aerial panchromatic images from the years 1949, 1971 and 1992 were used for interpretation of tendencies and trends in different types of stand textures. Spatial classification was established on the method of image segmentation. In the field, the total 98 segments at higher level covering 63 ha were localized and characterized in detail. A detailed descriptive system of the habitat, conservation, species, spatial and age structure of the segments was used. Research plots, detailed biometrically measured by FieldMap technology, were used as training plots for classification with RS data and as the calibration objects in a spatial description of the segments in the field. The presented approaches were verified in several model localities with the possibility of generalization for the entire range of forest communities in Slovakia. A multimedia system with records from the interior and exterior of typical stand structures and textures has been also implemented.

Key words: forest structure and texture, segmentation, thematic mapping, classification, remote sensing, multimedia records

Práca rieši problematiku tematického mapovania a posudzovania štruktúr lesných porastov vykonaného na báze kombinácie distančných a pozemných metód s využitím DPZ a GIS. Nadväzujúc na náš predchádzajúci výskum, prezentujeme výsledky tematického mapovania súborov porastových typov vykonaného na modelovom území Lomnistá dolina v Nízkych Tatrách (1 623 ha), štrukturálnych typov a prvkov, klasifikácie štruktúry a ekologickej stability horských lesov na modelových lokalitách Konštiaky, Široký úplaz, Martalúzka - Byčiarky v Nízkych Tatrách na výmere vyše 270 ha. Na príklade lokality Medvedia úboč (63 ha) v Lomnistej doline, resp. spoločenstiev prírodných lesov jedlovobukového vegetačného stupňa (vs), prezentujeme inovatívne metódy tematického mapovania segmentov a typov štruktúr lesných porastov na báze metód DPZ, GIS, metódy segmentácie a metódy mobilných technológií. Typy, prvky a segmenty porastových textúr sme identifikovali, lokalizovali a čiastočne aj klasifikovali na ortorektifikovaných digitálnych multispektrálnych leteckých snímkach aj s využitím satelitnej scény SPOT. Historické letecké panchromatické snímky z rokov 1949, 1971 a 1992 sme využili 
pri interpretácii tendencií a trendov vývoja typov porastových textúr. Plošnú klasifikáciu sme založili na metóde segmentácie obrazu. Lokalizovali sme a v teréne podrobne charakterizovali celkom 98 segmentov štruktúry lesa vyššej hierarchickej úrovne na výmere 63 ha. Použili sme podrobný systém popisu stanovišta, zachovalosti, druhovej, priestorovej a vekovej štruktúry segmentov lesa v teréne. Podrobné biometrické charakteristiky výskumných plôch zistené pomocou technológie FieldMap sme využili ako tréningové plochy pri klasifikácii z podkladov DPZ a ako objekty kalibrácie pri plošnom opise segmentov lesa v teréne. Prezentované prístupy sme overili na viacerých modelových lokalitách a získané výsledky možno zovšeobecnit pre celé spektrum lesných spoločenstiev Slovenska. Zaviedli sme tiež systém multimediálnych záznamov interiéru a exteriéru typických štruktúr a textúr lesných porastov.

Kl'účové slová: štruktúra a textúra lesa, segmentácia, tematické mapovanie, klasifikácia, DPZ, multimédiálne záznamy

\section{1. Úvod a ciel' práce}

Potreba výskumu, tematického mapovania a posudzovania štruktúry a textúry lesných spoločenstiev aj v súvislosti s ich predispozíciou k stabilite je argumentačne vel'mi silne zdôvodnená. Vyplýva predovšetkým z posúdenia miery súladu medzi aktuálnym (súčasným) a prírode blízkym, potenciálnym stavom lesných ekosystémov. Možné disproporcie spočívajú v nesúlade medzi aktuálnym a potenciálnym, stanovištne zdôvodneným zastúpením drevín a v zmenenej diverzite lesných spoločenstiev. Tiež medzi produkciou a stabilitou drevín dosahovanou v prírodných spoločenstvách a produkciou dosahovanou v ekologickom a fyziologickom optime týchto drevín. V možnom odklone od prírode blízkej štruktúry, najmä v zjednodušení, unifikácii aktuálnej priestorovej a výstavbovej štruktúry lesov. Vo významnom vplyve disturbancií a synergickom pôsobení škodlivých činitelov najmä v horských lesoch a v antropickom tlaku na lesné ekosystémy. V nepostačujúcom zohladňovaní širších priestorových a krajinno-ekologických súvislostí v praxi starostlivosti o lesy.

Pri riešení problematiky sme nadviazali na výsledky nášho predchádzajúceho výskumu dosiahnuté najmä v horských lesoch Slovenska (VLADovič et al., 1999; Vladovič, Bucha, 1999; Vladovič, 2003, 2004, 2005, 2007; MoRAvčík et al., 2002, 2005). Pri výskume horských lesov v projekte Výskum metód obhospodarovania horských lesov na princípe trvalo udržatelného rozvoja (MoravčíK et al., 2002) sme hodnotili spôsoby posudzovania porastových štruktúr smrekového vegetačného stupňa (vs), ako aj metódy plošného tematického mapovania, exaktného zaznamenania mozaikovitosti porastov a zmiešania štruktúrnych a textúrnych typov, ich vel'kosti, ako aj spôsobu hodnotenia plošných a priestorových vztahov spoločenstiev k modelu terénu, výškovým pásmam a stanovištným podmienkam na báze uplatnenia GIS a DPZ. V projekte podporenom Agentúrou na podporu výskumu a vývoja (APVV) Výskum metód klasifikácie a štrukturálnych modelov priaznivého stavu lesných ekosystémov Slovenska - Hodnotenie stavu a vývoja lesov $v$ krajine s podporou DPZ (VLADOvič et al., 2008, 2011) sme metodologické prístupy rozvinuli, zovšeobecnili a aplikovali aj v nižších vs. Pracovali sme v celej šírke edaficko-trofických pomerov lesov Slovenska.
V predkladanej práci sme nadviazali na dynamický rozvoj materiálov a technológií najmä leteckého, ale aj satelitného DPZ, ako aj na zaujímavé a dostupné novšie metódy spracovania obrazu krajinných štruktúr. Pozornosî sme sústredili predovšetkým na horské lesy 5. až 7 . vs. Kombináciu distančných a pozemných metód považujeme za vysoko efektívnu ,pridanú hodnotu“ lesnícko-ekologického výskumu v oblasti mapovania a posudzovania štruktúry a textúry lesných spoločenstiev, zistovania a posudzovania ich stavu a vývoja. Takéto „,posudzovanie lesa" je potrebné vykonávat najmä v kontexte širších priestorových súvislostí v krajine.

Cielom práce je preskúmå a prispiet $\mathrm{k}$ inovácii metód tematického mapovania a posudzovania porastových štruktúr a textúr v horských lesných ekosystémoch s uplatnením kombinácie distančných (DPZ) a pozemných metód.

\section{Metodika a empirický materiál}

Rámcová schéma metodického prístupu riešenia, ktorý sme uplatnili pri tematickom mapovaní a posudzovaní porastových štruktúr na báze uplatnenia pozemných a distančných prístupov, je zobrazená na obrázku 1 . Využili sme modely terénu, letecké snímky (historické aj aktuálne), satelitné scény, GIS vrstvy jednotiek rozdelenia lesa (JPRL) a vrstvy typologických, geologických a pedologických jednotiek.

Počas prípravných a mapovacích prác sme $\mathrm{v}$ teréne lokalizovali a zamerali výskumné, monitorovacie, inventarizačné a d’alšie dostupné a využitelné plochy. Lokalizovali sme a v teréne viditel'ne označili aj nepravidelnú siet orientačných, navigačných, opisných, referenčných a d’alších bodov a polygónov potrebných $\mathrm{k}$ zosúladeniu prác terénneho mapovania a k relatívnemu zjednoteniu polohovej presnosti GIS vrstiev z terénnych zistovaní a mapovaní. Siet orientačných, navigačných a popisných bodov sme zamerali zariadeniami GPS Trimble Recon a Trimble pocket PC.

$\mathrm{V}$ teréne sme tieto body vyznačili žltou signalizačnou farbou na viditelných miestach - bralkách, balvanoch, stromoch (obr. 2d). Výskumné plochy prevažne kruhového tvaru so štandardizovanou výmerou $1000 \mathrm{~m}^{2}$ (obr. 2a) sme v strede stabilizovali pomocou kovového kolíka a tri blízke stromy sme označili bielym pruhom. Strom najbližší k stredu plochy (stredový strom) sme ozna- 


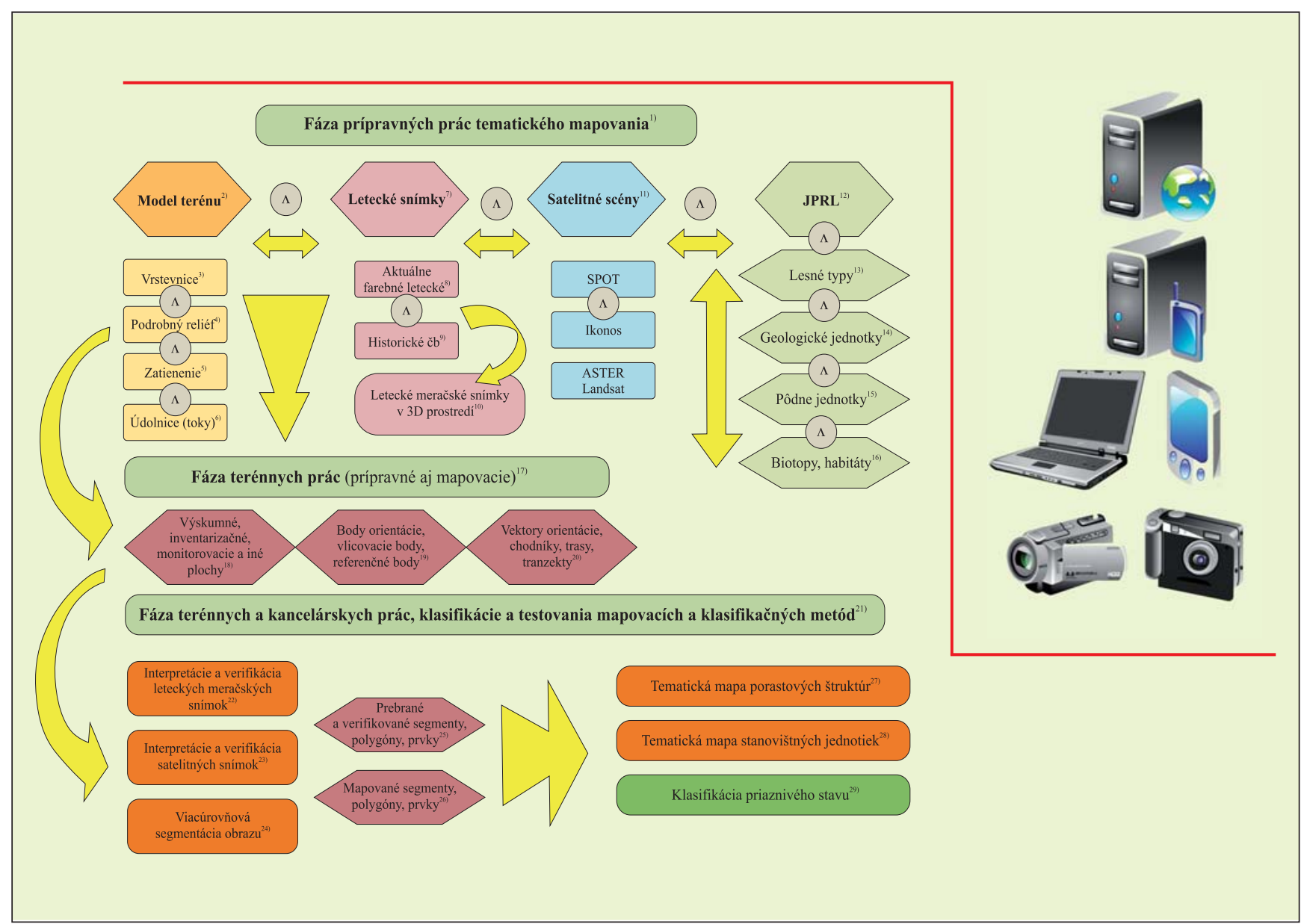

Obr. 1. Rámcová schéma metodického prístupu pri tematickom mapovaní a posudzovaní porastových štruktúr Fig. 1. Framework scheme of methodology in thematic mapping and assessment of stand structures

1)Preparatory phase of thematic mapping, 2)Terrain model, ${ }^{3)}$ Level lines, ${ }^{4}$ Detailed relief, 5) Obscuration, 6)Thalwegs (course), ${ }^{7)}$ Aerial images, ${ }^{8}$ Actual colour aerial, ${ }^{9}$ Historical monochrome, ${ }^{10}$ Aerial images in $3 D$ environment, ${ }^{11}$ Satellite scenes, $\left.{ }^{12}\right)$ Forest spatial division units, ${ }^{13}$ Forest types, ${ }^{14}$ ) Geological units, ${ }^{15}$ Soil units, ${ }^{16}$ Habitats, ${ }^{17}$ Fieldwork phase (preparatory, mapping), ${ }^{18}$ Research, inventory, monitoring and other plots, ${ }^{19}$ Orientation points, control points, reference points, ${ }^{20}$ Orientation vectors, trails, routs, transects, ${ }^{21)}$ Fieldwork and office work phase, classification and testing of mapping and classification methods, ${ }^{22}$ Interpretation and verification of $3 D$ aerial images, ${ }^{23}$ Interpretation and verification of satellite scenes, ${ }^{24}$ Multilevel image segmentation, ${ }^{25}$ )Verified segments, polygons, elements, ${ }^{26)}$ Mapped segments, polygons, elements, ${ }^{27}$ Thematic map of stand structures, ${ }^{28}{ }^{2}$ Thematic map of site units, ${ }^{29}$ Classification of the favourable condition

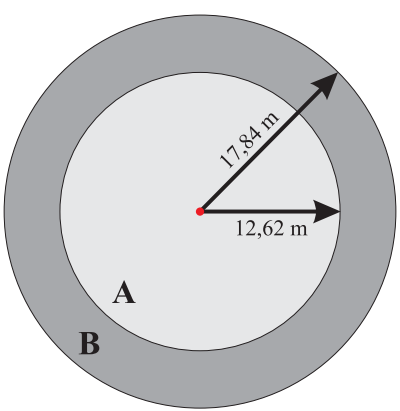

Obr. 2 a. Dizajn typologickej reprezentatívnej výskumnej plochy (TRVP)

Fig. 2 a. Design of typological representative research plot

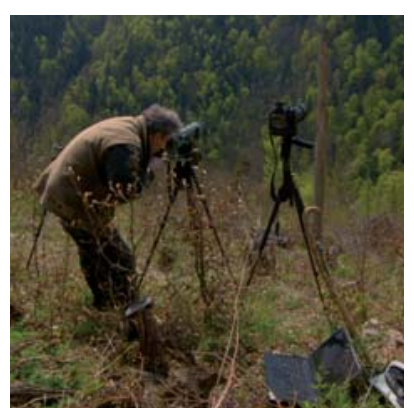

Obr. 2 b. FieldScope - metóda identifikácie porastových textúr a snímkovanie z protilahlého svahu

Fig. 2b. FieldScope-method of stand textures identification and photography from the opposite slope

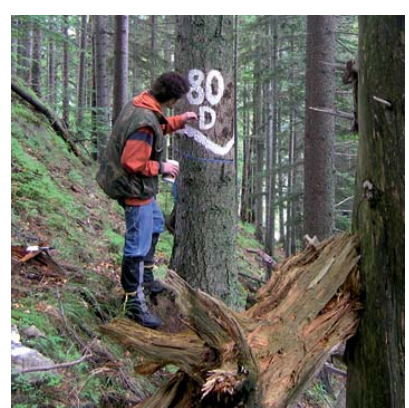

Obr. 2 c. Stabilizácia a označenie stredového stromu na TRVP

Fig. 2 c. Stabilization and marking of the central trees on the research plot

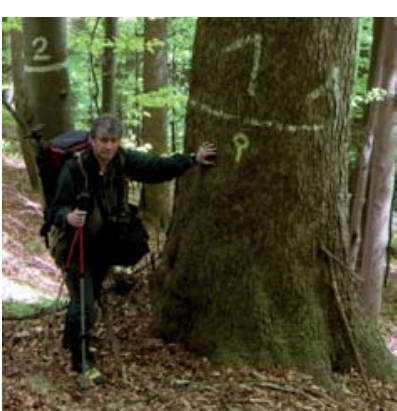

Obr. 2 d. Orientačný bod umiestnený na ploche pre monitorovanie biodiverzity (BMP)

Fig. 2 d. Orientation point located in the area for biodiversity monitoring 
čili bielym pruhom skloneným smerom na sever a číslom plochy (obr. 2c) v zmysle metodiky VlaADOVIČA et al. (2005).

$\mathrm{V}$ tejto práci uvádzame len podstatné časti podrobnejších prístupov tematického mapovania a posudzovania porastových štruktúr na báze digitálnych multispektrálnych leteckých meračských snímok, ktoré NLC Zvolen už štandardne zabezpečuje a využíva pri hospodársko-úpravníckych prácach a zostavovaní programov starostlivosti o lesy (predtým lesné hospodárske plány - LHP).

Tematické mapovanie súborov porastových typov sme vykonali v modelovom území Lomnistá dolina (obr. 3), mapovanie štrukturálnych typov na modelových lokalitách (ML) Konštiaky (obr. 4a), Široký úplaz (obr. 4b) v d’umbierskej časti Nízkych Tatier a Martalúzka - Byčiarky (obr. 4c) v královoholskej časti Nízkych Tatier.

Inovatívne metódy pri tematickom mapovaní a posudzovaní štruktúry na báze uplatnenia DPZ, GIS, metód segmentácie a uplatnenia mobilných technológií prezentujeme na príklade modelovej lokality Medvedia úboč (obr. 6) v Lomnistej doline.

\section{Výsledky}

Ako východiská výskumu uvádzame predovšetkým výsledky z tematického mapovania a posúdenia porastových štruktúr a textúr s uplatnením kombinácie pozemných a distančných metód a postupov.

\subsection{Tematické mapovanie vykonané v oblasti horských lesov $v$ rokoch 1998 - 2000}

Na modelových lokalitách (ML) v Nízkych Tatrách sme nadviazali na problematiku tematického mapovania súborov porastových typov, mapovania typov a prvkov štruktúry porastov

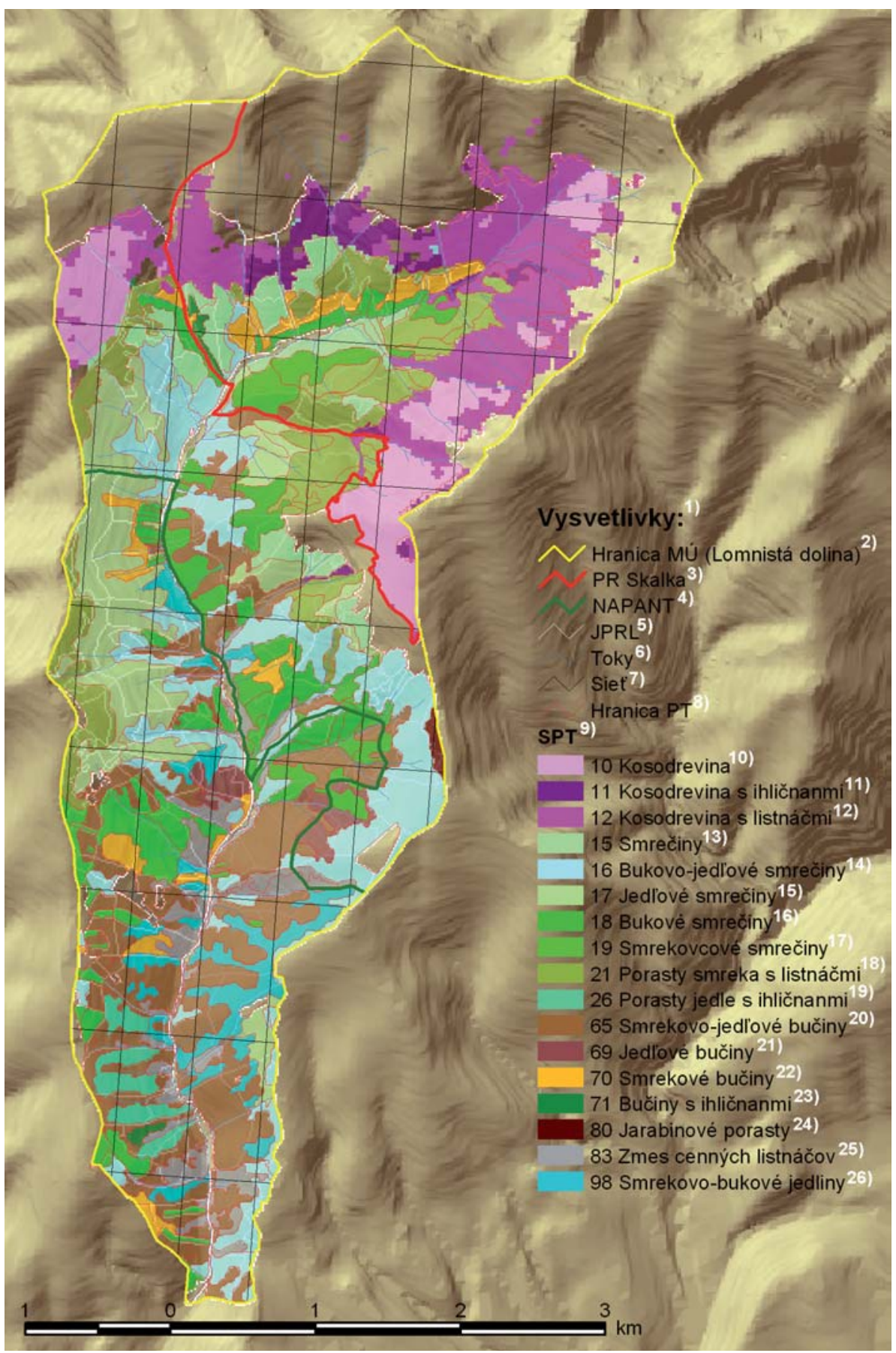

Obr. 3. Tematická mapa súborov porastových typov vytvorená na podklade satelitnej scény SPOT a výsledkov terestrického mapovania; ML Lomnistá dolina (1 623 ha); (Vladovič, Bucha, 1999; Vladovič, 2003)

Fig. 3. Thematic map of set of stand types based on a satellite scene SPOT and the results of terrestrial mapping ML Lomnistá Valley (1 623 ha); (VLADOVIČ, BUCHA, 1999; VLADOVIČ, 2003)

${ }^{1)}$ Notes, ${ }^{2)}$ Line of the monitoring plot, ${ }^{3)}$ Nature reserve Skalka, ${ }^{4}$ Low Tatras National Park, ${ }^{5}$ Forest spatial division units, ${ }^{6)}$ Courses, ${ }^{7)}$ Network, ${ }^{8)}$ Line of stand types, ${ }^{9}$ Sets of stand types, $\left.{ }^{10}\right)$ Dwarf pine, $\left.{ }^{11}\right)$ Dwarf pine with coniferous tree species, $\left.{ }^{12}\right)$ Dwarf pine with broad-leaved tree species, ${ }^{13}$ Spruce forests, ${ }^{14}$ Beech and fir spruce forests, ${ }^{15}$ Fir spruce forests, ${ }^{16}$ Beech spruce forests, ${ }^{17)}$ Larch spruce forests, ${ }^{18}$ Spruce stands with broad-leaved tree species, ${ }^{19}$ Fir stands with coniferous tree species, ${ }^{20}$ Spruce and fir beech forests, ${ }^{21}$ Fir beech forests, ${ }^{22}$ Spruce beech forests, ${ }^{23}{ }^{3}$ Beech stands with coniferous tree species, ${ }^{24)}$ Rowan stands, ${ }^{25}$ Mixture of valuable broad-leaved tree species, ${ }^{26)}$ Spruce and beech fir forests 

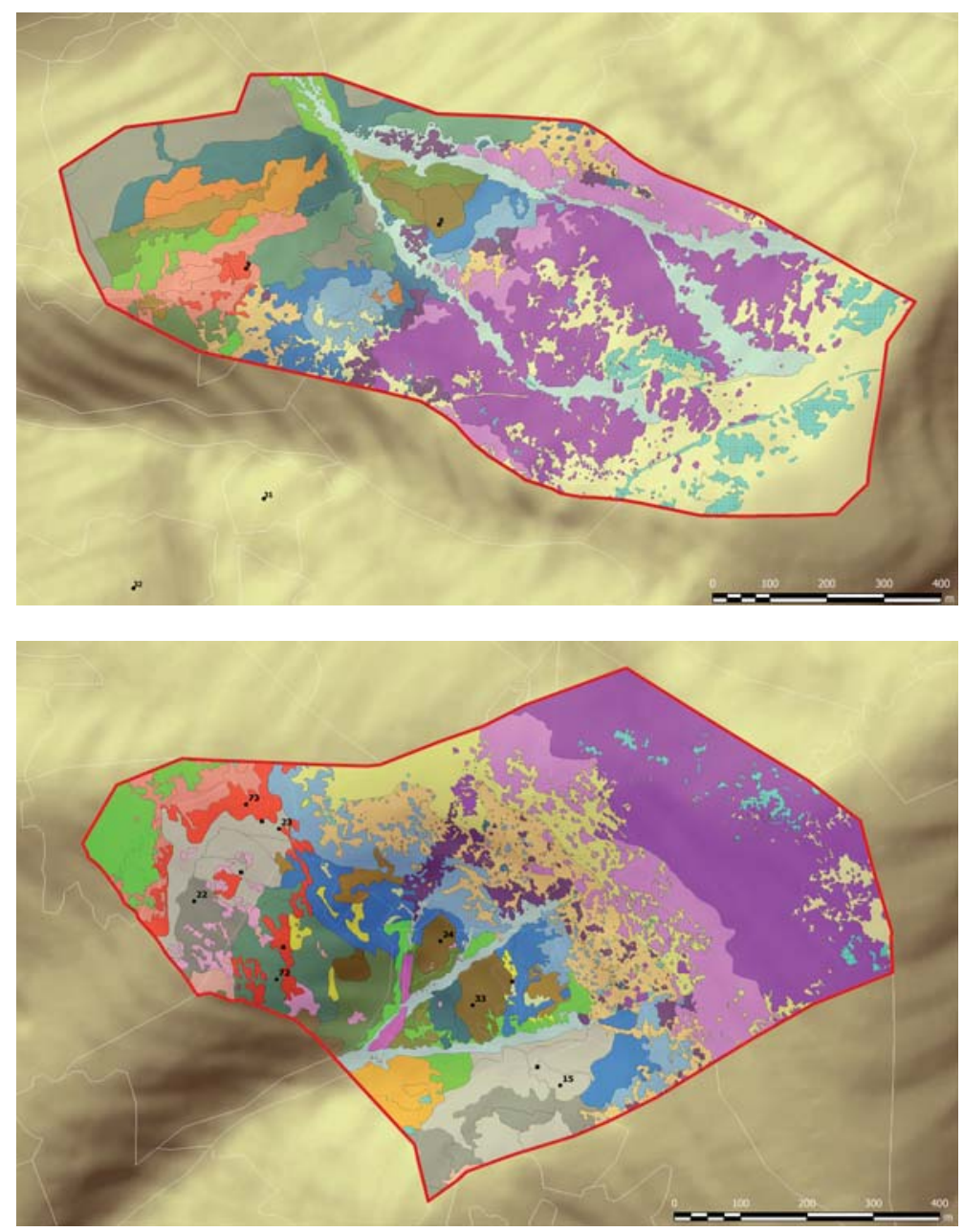

Obr. 4. Tematické mapy štrukturálnych typov a prvkov zhotovené na podklade ortorektifikovaných leteckých snímok a výsledkov terénneho mapovania s podporou GPS; 4a) ML Konštiaky (71 ha) a 4b) ML Široký úplaz (59 ha) v d’umbierskej časti Nízkych Tatier, 4c) ML Martalúzka - Byčiarky (141 ha) v královohol’skej časti Nízkych Tatier

Fig 4. Thematic maps of structural types and segments based on orthorectified aerial images and results of terrain mapping with GPS support, 4a) ML Konštiaky (71 ha) and 4b) ML Široký úplaz (59 ha) in part Ďumbier of Low Tatras, 4c) ML Martalúzka - Byčiarky (141 ha) in part Králova hola of Low Tatras ${ }^{1)}$ Colour, ${ }^{2}$ Short description of the structural types (selection), ${ }^{3} D$ warf pine stands, ${ }^{4}$ Rowan and dwarf pine stands with spruce, ${ }^{5}$ Abandoned grasslands on mountain meadows with a succession stage of forests (with spruce, dwarf pine and rowan), ${ }^{6}$ Avalanche channels with partial presence of tree species (spruce, rowan, dwarf pine) and coverage of 5\%, ${ }^{7}$ Natural mature spruce forests (partially with fir or beech), low age differentiated with a minimal natural regenartion, canopy 60 to $75 \%$, (partially with rowan), dense stands with a canopy, not tended with a low static stability and low natural regeneration, ${ }^{9}$ Prevailing natural mature spruce stands with rowan, age differentiated, biogroups with a low generative natural spruce regeneration, canopy 55 to $80 \%$, ${ }^{10}$ Natural growing spruce foresta with rowan (partially with fir, beech and Acer pseudoplatanus) medium age differentiated, canopy 70 to $90 \%$, ${ }^{11)}$ Prevailing natural pre-mature and mature spruce forests (partially with rowan), age differentiated with a differentiated structure, canopy 50 to $90 \%,{ }^{12}$ Natural mature spruce forests with beech, partially with fir, low age differentiated, low natural regeneration, canopy approx. $\left.80 \%,{ }^{13}\right)$ Natural mature spruce forests (partially with fir and beech), highly age differentiated with an average natural regeneration, canopy $90 \%,{ }^{14}$ Calamitous (an early) and complete decline of natural spruce forests with a minimal natural regeneration, canopy $10-30 \%,{ }^{15}$ Partially afforested (artificial) or partially naturally regenerated areas after windfalls with standing calamitous residues, ${ }^{16)}$ Reduced clearings, so called holes in the stand mostly without continuous stands with canopy not exceeding 10 only 30\%, ${ }^{17}$ Natural mature spruce-fir beech forests, medium age differentiated with an average regeneration, canopy 75 to 90\%, ${ }^{18}$ Partially changed (artificial) pre-mature even aged spruce forests from artificial plantings (partially with rowan and beech) after windfall low tended, static stable, ${ }^{19}$ Totally destructed stand structures by avalanches, ${ }^{20}$ Partial decline of calamitous feature, ${ }^{21}$ Spruce solitaires and clusters, age differentiated, as part of succession forest stages of higher altitude $>1400 \mathrm{~m} \mathrm{n.} \mathrm{m}$. 
a klasifikácie štruktúry horských lesov, ktorú sme riešili v Lesníckom výskumnom ústave v rokoch 1998 až 2000 (Vladovič et al. 1999, Vladovič, Bucha 1999, Vladovič 2000, 2003, 2004, VladoviČ et al. 2007 a, b) (obr. 3 a 4).

Problematiku tematického mapovania aktuálnej vegetácie - porastových typov a ich súborov sme riešili aj overili na príklade modelového územia Lomnistá dolina, na ploche 1623 ha. Orientovali sme sa na uplatnenie družicových scén SPOT, Landsat, leteckých a pozemných farebných fotografických snímok a videozáznamov, leteckých infračervených snímok, údajov LHP, špeciálnych prieskumov a podrobných terénnych zistovaní stavu lesa. Analýzou zmapovaných súborov porastových typov v segmentoch skupín lesných typov vo vztahu k údajom z modelu terénu sa v prostredí GIS získali dôležité poznatky o vertikálnom a priestorovom rozšírení lesných spoločenstiev (Vladovič, Bucha, 1999).

Pri tematickom mapovaní typov porastových štruktúr sme sa sústredili na posúdenie možnosti typizácie štruktúry horských lesov a stanovenie miery odchýlky súčasného stavu horských lesov od stavu prírodných lesov. Odvodili a overili sme metódu tematického mapovania porastových typov a typov porastových štruktúr ako kombináciu uplatnenia pozemného terénneho mapovania, DPZ a GIS. Tematické mapovanie sa vykonalo na základe nami navrhnutého postupu s podporou v teréne fixovaných TVP, pomocných referenčných bodov a polygónov s využitím metódy GPS, leteckých a pozemných snímok, videozáznamov a satelitných scén (Ikonos, Landsat, SPOT). Podrobné mapovanie sme vykonali na troch modelových lokalitách, z ktorých dve sa nachádzajú v Lomnistej doline v d’umbierskej časti Nízkych Tatier - ML Konštiaky a ML Široký úplaz (obr. 4a, b) a jedna lokalita je v oblasti Prírodnej rezervácie Martalúzka a jej prilahlom okolí - ML Martalúzka - Byčiarky v královohol'skej časti Nízkych Tatier (obr. 4c). Pri hodnotení stavu lesa sme sa orientovali aj na odvodenie priestorového rozmiestnenia a striedania - mozaikovitosti a diverzity jednotlivých štruktúrnych typov a prvkov a ich vývojových tendencií a trendov, s využitím časovej rady historických leteckých snímok z rokov 1949, 1962, 1973, 1986, 1998, (2000 Ikonos). Naše výsledky korešpondujú s Korpel'ovými poznatkami (KoRPEL, 1989), že vel'kosî mozaikových častí a plošný podiel štrukturálnych typov, vývojových štádií a vývojových fáz, z celkovej posudzovanej výmery lesa sú dobrými ukazovatel'mi vyrovnanosti rastových a vývojových procesov a stability spoločenstva.

Typ porastovej štruktúry (štrukturálny typ) sme definovali ako typizačnú jednotku aktuálnej vegetácie s dôrazom na posúdenie drevinovej zložky lesných ekosystémov. Pri typizácii sme odvodili stupne prirodzenosti (zachovalosti) porastov a zaznamenali sme najdôležitejšie charakteristiky a znaky druhovej, vekovej a priestorovej štruktúry lesa. Druhová štruktúra porastov bola reprezentovaná súborom porastových typov, porastovým typom a zastúpením drevín. Veková štruktúra mozaikovitostou vývojových štádií a fáz a vekovou rozrôznenostou porastov. Priestorovú štruktúru sme charakterizovali prostredníctvom horizontálnej a vertikálnej štruktúry porastu, t. j. na základe zmiešania, formy a stupňa zápoja a výstavby porastu. Súčastou posudzovania bolo aj hodnotenie prirodzeného zmladenia a zdravotného stavu lesa.

\subsection{Aktuálne inovatívne prístupy a metódy}

Na modelovej lokalite Medvedia úboč v Lomnistej doline, v Nízkych Tatrách (obr. 5, 6) sme na uvedené práce nadviazali v rokoch 2008 - 2011. Práce sme orientovali na výskum a overovanie inovatívnych metód tematického mapovania a klasifikácie na báze uplatnenia DPZ, GIS, metód segmentácie a uplatnenia mobilných technológií.

\subsubsection{Modelová lokalita Medvedia úboč}

Modelová lokalita (ML) Medvedia úboč (obr. 5, 6) sa nachádza v Lomnistej doline, v lesnej oblasti 46 Nízke Tatry v podoblasti Ďumbier, Prašivá, čast juh (VLADOVIČ et al., 1994). Organizačne patrí do lesnej správy Predajná. Ide o zachovalý komplex prevažne prírodných lesov aj lesov pralesového charakteru v oblasti jedlovo-bukového vegetačného stupňa, patriacich do kategórie ochranných lesov.

Porastová plocha spracovaného územia je 63 ha. Priemerný sklon terénu je $32^{\circ}$ a nadmorská výška sa pohybuje od 684 do $1054 \mathrm{~m} \mathrm{n}$. m. Podklad je tvorený metamorfovanými horninami, najmä migmatizovanými ortorulami s niekol'kými ostrovmi amfibolitov. Územie sa nachádza v jedlovo-bukovom vegetačnom stupni.

Lokalitu sme v rámci výskumu podrobne typologicky zmapovali segmentovou metódou. Vyhotovili sme tiež podrobné tematické fyzickogeografické mapy. V zmysle geobiocenologickej typizácie ZlatníKA (1959) prevažujú skupiny lesných typov Abieto-Fagetum inf. (33\%), Fageto-Abietum inf. (27\%), Fageto-Aceretum inf. (26\%), Fraxineto-Aceretum inf. (12\%). V každom segmente lesa sa zaznamenal aj aktuálny stav drevinovej zložky na úrovni súborov porastových typov (SPT).

$\mathrm{Na}$ ML sme lokalizovali a v teréne viditel'ne vyznačili (obr. 6) celkom 109 pomocných referenčných bodov, z toho 7 navigačných, 68 orientačných a 34 opisných. Boli významným prínosom pri terénnych mapovacích prácach, najmä čo sa týka orientácie a navigácie $\mathrm{v}$ náročnom balvanitom a bralnatom horskom teréne s vel'kou dynamikou reliéfnych tvarov, polohového zjednotenia a relatívneho zjednotenia presnosti mapovaných vrstiev GIS.

\subsubsection{Výskumné plochy ako objekty kalibrácie pre pozemné a distančné zistovania porastových dát a tematické mapovanie}

V rámci výskumu sme na modelovej lokalite založili 11 a technológiou FieldMap podrobne zmerali 10 re- 

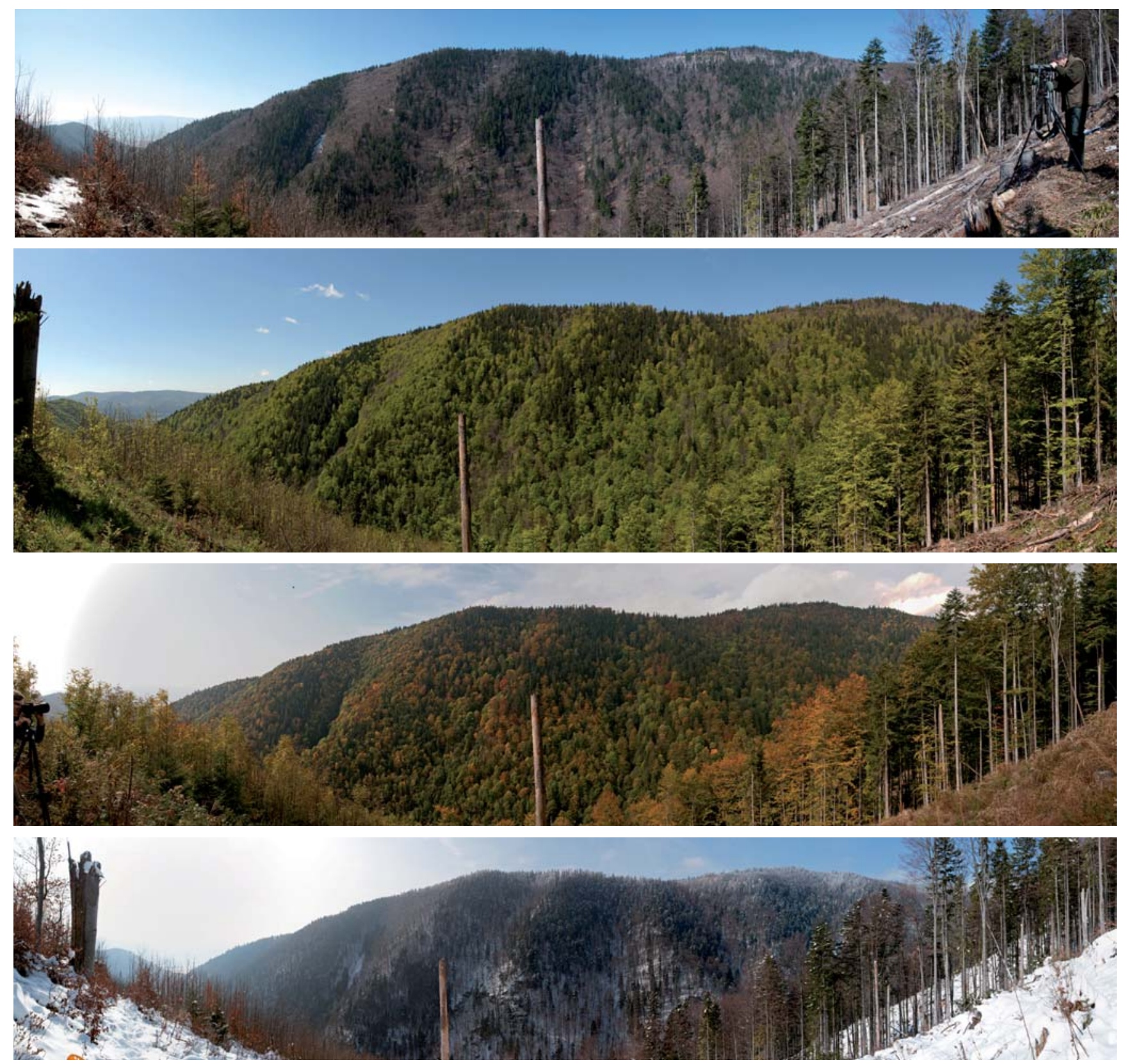

Obr. 5. Panoramatické zábery modelovej lokality Medvedia úboč v Lomnistej doline urobené z protilahlého svahu. V rôznych fenologických obdobiach snímkovania porastov (obr. 5a - 2. 4. 2009; obr. 5b - 7. 5. 2009; obr. 5c - 8. 10. 2009 ; obr. 5d - 10. 2. 2010) sú zretel'ne viditel'né rôzne typy porastových textúr a druhovej štruktúry porastov a na snímkach z obdobia vegetačného pokoja (obr. 5d) možno identifikovat aj vztah drevinovej zložky k morfológii a dynamike reliéfu

Fig. 5. Panorama images of ML Medvedia úboč in Lomnistá Valley taken from the opposite slope. In different phenological stages of photography (fig. 5a-2. 4. 2009; fig. 5b-7. 5. 2009; fig. 5c-8. 10. 2009; fig. 5d-10. 2. 2010) different types of stand textures and species structure are visible and we can identify relation of tree species to morphology and dynamics on photos from the still stage of vegetation (fig. $5 d$ )

prezentatívnych trvalých výskumných plôch kruhového tvaru so štandardizovanou výmerou $1000 \mathrm{~m}^{2}$ (tab. 1). Výskumné plochy sme zakladali v plošne prevažujúcich štrukturálnych typoch posudzovaného územia. Sú technológiou GPS presne polohovo lokalizované a vizualizované v prostredí ArcGIS a v systéme Stand Visualisation System (SVS) (obr. 7, 8). Uplatňujú sa pri katalogi- zácii štrukturálnych modelov priaznivého stavu lesných ekosystémov a sú tiež tréningovými plochami pri klasifikáciách z podkladov DPZ. Na týchto podrobne meraných plochách sme zaškolili riešitelov projektu na vykonávanie mapovacích prác v teréne. Na ML sme lokalizovali ešte d’alších 14 výskumných a monitorovacích plôch, z toho 1 plochu národnej inventarizácie a moni- 


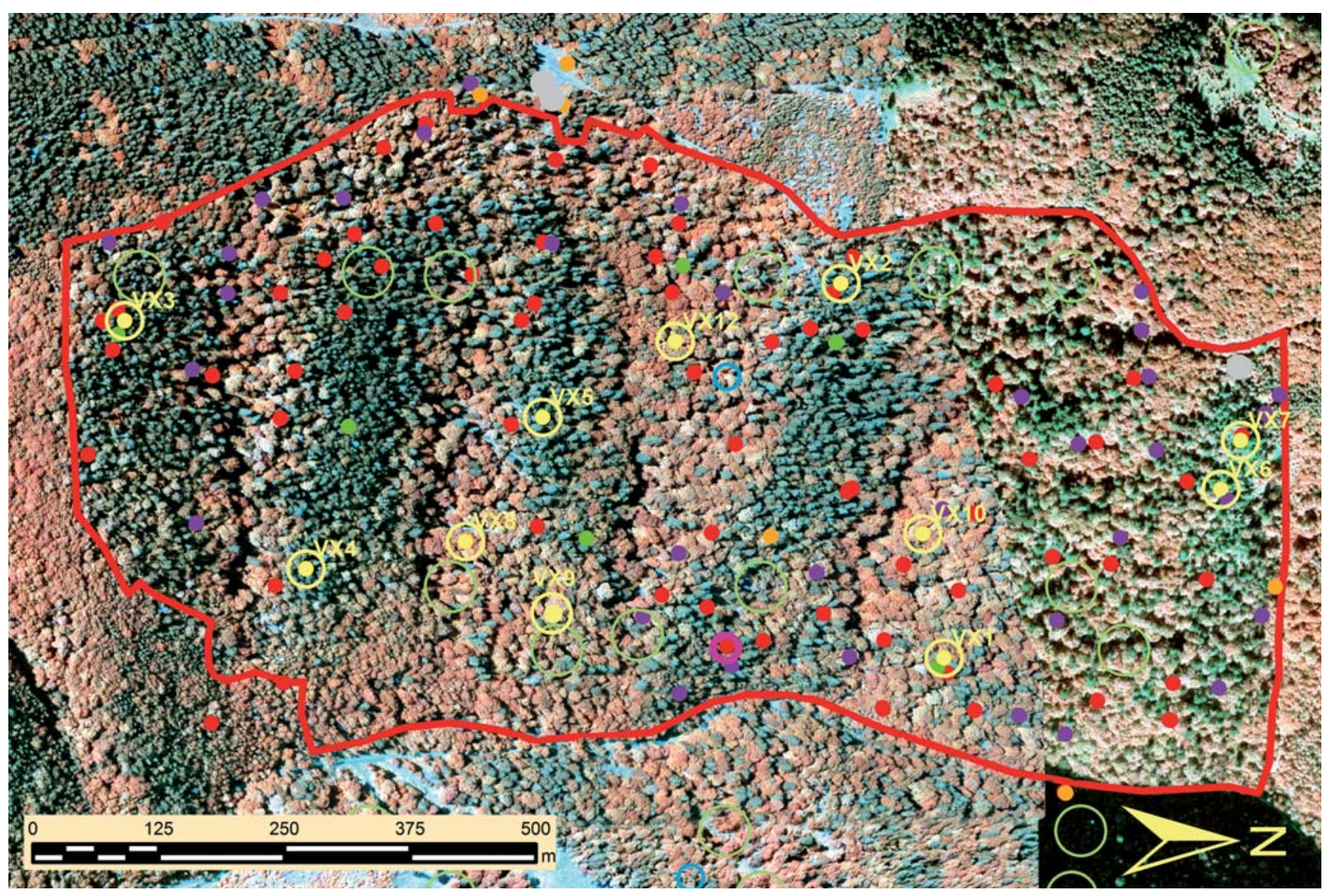

Obr. 6. ML Medvedia úboč s lokalizáciou výskumných plôch, siete v teréne fixovaných orientačných, navigačných a popisných bodov - CIR kompozícia na mozaike leteckých snímok z roku 2008, 2009 (PHOTOMAP, s. r. o., Košice pre NLC Zvolen, 2008, 2009)

Fig. 6. ML Medvedia úboč with the localisation of research plots, network in a terrain of fixed, orientation, navigation and reference points - CIR composition on a mosaic of aerial images from 2008, 2009 (PHOTOMAP, s. r. o., Košice pre NLC Zvolen, 2008, 2009)

toringu lesov (NIML), 1 plochu pre monitorovanie biodiverzity a 11 plôch pre monitorovanie biotopov.

Obrázky 7 a 8 sú výsledkom prepojenia informácií výstavbovej štruktúry z pozemného merania TRVP technológiou FieldMap a textúry porastov na báze leteckého DPZ na multispektrálnych snímkach. Hlavnými parametrami kalibrácie, sledovanými na výskumných plochách vo vzlahu k následným pozemným zistovaniam plošných dát, boli najmä parametre vertikálnej a horizontálnej štruktúry a zachovalosti (prirodzenosti) porastov, a to:

a) podiel vrstiev vertikálnej výstavbovej štruktúry podla Zlatníka (1963, 1976);

b) podiel ležiaceho odumretého dreva (podla drevín) z celkovej drevnej zásoby na ploche;

c) druh, stupeň, forma zmiešania, zastúpenie drevín a zápoj - horizontálna štruktúra;

d) podiel stojacich suchárov a vitalita; a d’alšie kvantitatívne aj kvalitatívne charakteristiky, ktoré možno porovnat s veličinami odhadovanými pri ma- povaní a opise segmentov v rámci plošného mapovania. Prehlad niektorých vybraných charakteristík z výskumných plôch uvádzame v tabul'ke 1. Štruktúru charakteristík zisłovaných v segmentoch lesa v rámci tematického mapovania uvádzame v schéme na obrázku 14.

\subsubsection{Multimediálne záznamy interiéru a exteriéru porastových štruktúr a textúr}

Za účelom interaktívnych prístupov výskumu a lepšieho sprístupňovania podkladov a výsledkov sme rozpracovali a overili systém multimediálnej vizualizácie a prezentácie výskumných plôch, objektov a modelových lokalít. Systém sa osvedčil aj priamo pri posudzovaní, vyhodnocovaní, kalibrácii aj interpretácii empirického materiálu pochádzajúceho z tematického mapovania.

Vychádzali sme z multimediálnej vizualizácie a prezentácie štruktúry lesných spoločenstiev na modelových lokalitách, reprezentatívnych výskumných plochách a objektoch v širšom kontexte textúr porastov a krajiny. Uplatnili sme systém vizualizácie a spracovania repre- 


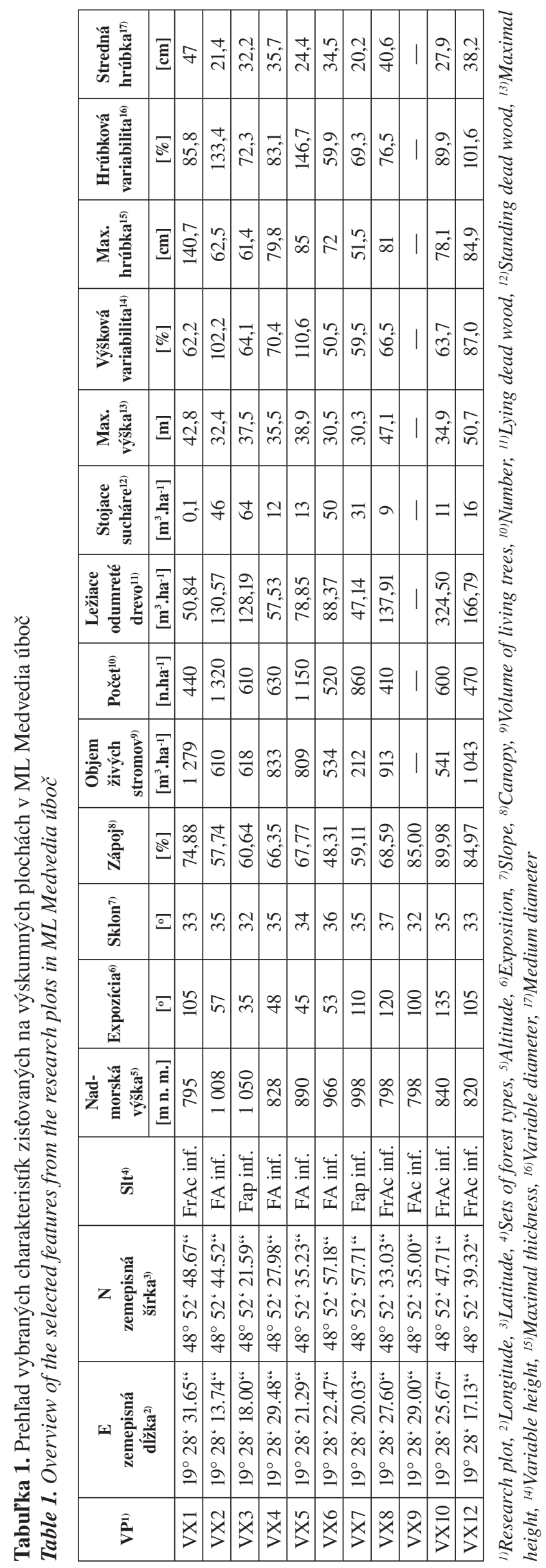

zentatívnych modelových plôch a objektov zjednotený $\mathrm{v}$ geografickom informačnom systéme (GIS) na podklade digitálneho modelu terénu (DMT) a podkladov DPZ (leteckých a satelitných snímok). Reprezentatívne výskumné plochy exaktne merané technológiou FieldMap sme vizualizovali v prostredí GIS, v systéme Stand Visualisation System (SVS, McGaugheY, 2002). Vizualizujú sa jednotlivé stromy, projekcie korún a odumreté drevo. Na všetkých výskumných plochách sme okrem podrobného biometrického merania technológiou FieldMap vykonali tiež systematické snímkovanie interiéru porastu, fytocenózy a pedologickej sondy, hemisférické snímkovanie zo stredu VP do korunovej sféry. Zabezpečili sme aj interaktívne kruhové fotopanorámy $360^{\circ}$ vybraných reprezentatívnych výskumných plôch a d’alších objektov, ktoré umožňujú riešitelom a užívatelom interaktívny pohyb v priestore a detailné zosúladenie a vizualizáciu výskumom zabezpečeného empirického materiálu (obr. 10). Vyhotovili sme tiež systém sekvencií videozáznamov polohovo lokalizovaných pomocou GPS. Štandardne sme zhotovili kruhové horizontálne videozáznamy interiéru VP $\left(360^{\circ}\right)$ zo stredu, ako aj vertikálny stredový $\left(360^{\circ}\right)$ videozáznam do korún. Ďalej sekvencie interiéru porastu VP oproti spádnici a po vrstevnici z oboch vonkajších strán do vnútra plochy, podla schémy na obrázku 9 .

Priebežne sme vyhotovovali a archivovali systém digitálnych fotografií interiéru a exteriéru porastových štruktúr lesných spoločenstiev aj mimo výskumných plôch, vrátane hemisférických snímok vybraných objektov. Textúry sme spracovali z podkladov DPZ a pozemných snímok z protisvahu a panorám reprezentatívnych lokalít a objektov so zachovalými lesnými spoločenstvami (ukážky sú na obr. 6, 11, 12). Súčastou systému je aj grafické zobrazenie hlavných ukazovatelov druhovej a priestorovej štruktúry porastov, vychádzajúcich z kritérií a indikátorov ich priaznivého stavu.

Pozemné snímkovanie modelových lokalít v rôznych fenologických fázach (aspektoch) porastov aj v období vegetačného pokoja (ukážky na obr. 5 a 11) sme z protilahlého svahu robili opakovane. Snímky a videozáznamy majú výborné rozlíšenie a umožňujú identifikovat, konfrontovat a interpretovat štruktúrne prvky, segmenty, ale i jednotlivé stromy. Pri terénnej identifikácii sa nám osvedčila zostava monokuláru so statívom a adaptérom na fotoaparát, binokulárny dalekohlad, digitálna videokamera HD s GPS, digitálna zrkadlovka so širokouhlým objektívom a teleobjektívom a s GPS. V teréne sme tiež využili terénny notebook v kombinácii s meračským a turistickým (navigačným) prístrojom GPS. Digitálne multimediálne záznamníky sa osvedčili najmä v nepriaznivom počasí pri opise segmentov porastov. 

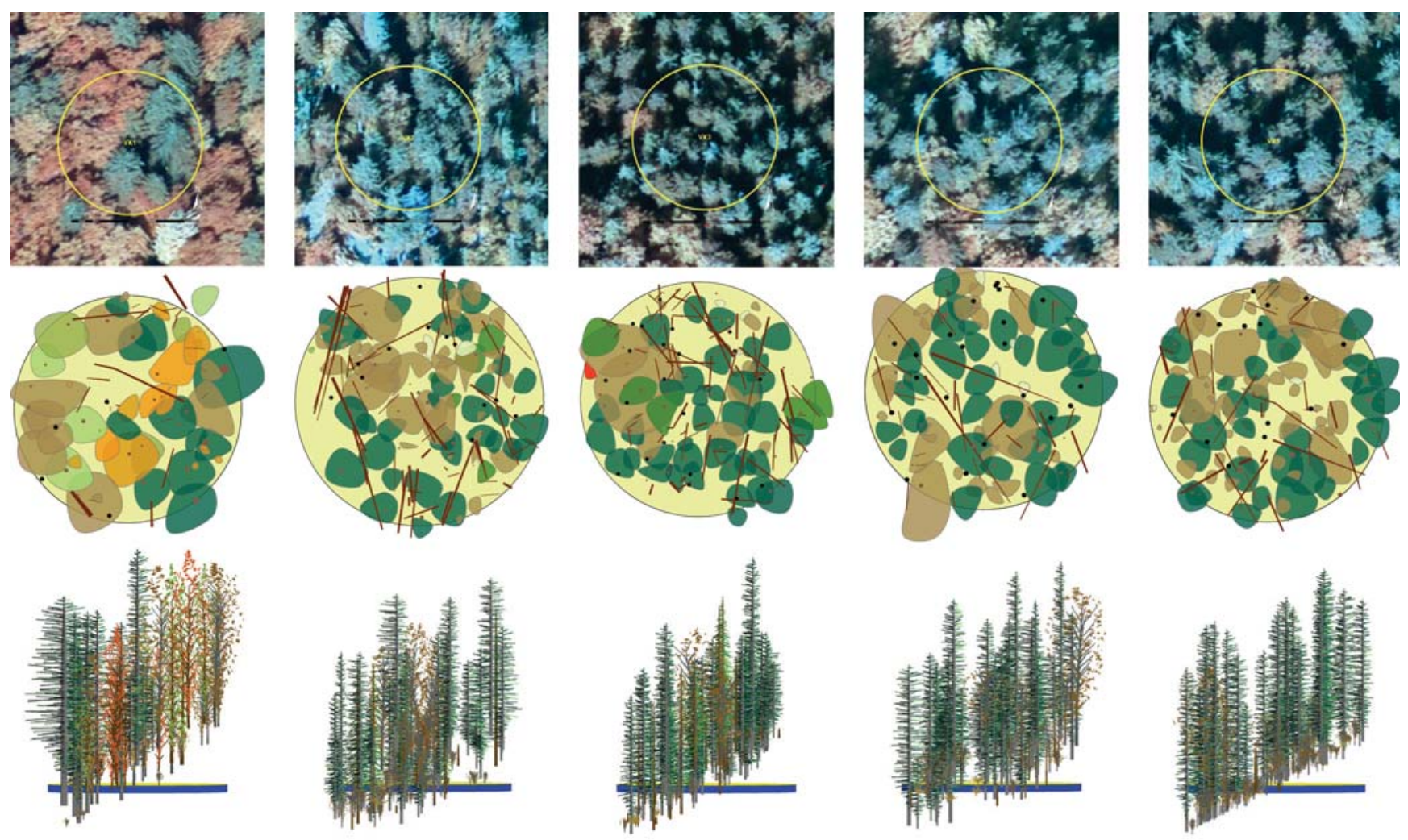

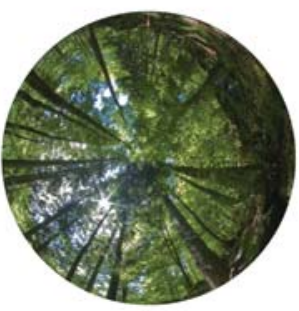

VX1

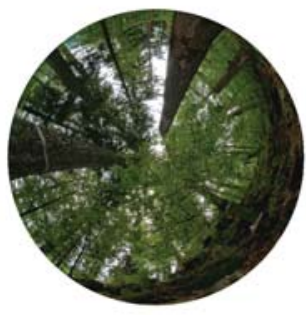

VX2

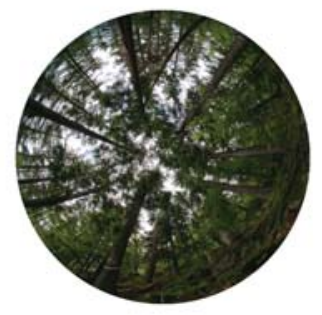

VX3

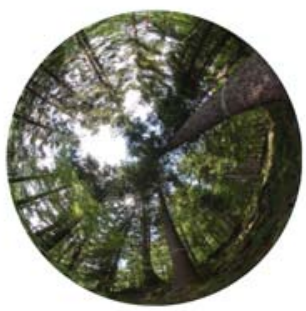

VX4

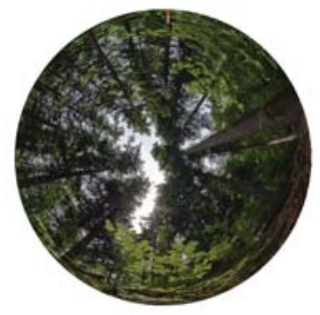

VX5

Obr. 7. Textúra a štruktúra lesných porastov na výskumných plochách v ML Medvedia úboč

Fig. 7. Texture and structure of forest stands on research plots in ML Medvedia úboč

\subsubsection{Segmentácia na báze DPZ, ako východisko pre ohraničenie porastových štruktúr a textúr a ich klasifikáciu}

Jednotlivé typy a prvky porastových textúr sme identifikovali, lokalizovali a čiastočne aj klasifikovali na ortorektifikovaných digitálnych multispektrálnych leteckých snímkach s priestorovým rozlíšením pixelu $20 \mathrm{~cm}$ (obr. 6, 12). Štandardne sme uplatnili aj aktuálnu satelitnú scénu SPOT s $10 \mathrm{~m}$ priestorovým rozlíšením a historické letecké panchromatické snímky z rokov 1949, 1971 a 1992 (obr. 13), ktoré sme využili pri interpretácii tendencií a trendov vývoja jednotlivých typov porastových textúr. Plošná klasifikácia je založená na metóde segmentácie obrazu na snímkových podkladoch DPZ pomocou softvéru Definiens Developer.

Územie sme rozčlenili na segmenty rámcovo homogénne z hladiska štruktúry a textúry porastov. Významnou mierou sa tým zlepšia možnosti racionalizácie me- tód pozemného tematického mapovania a klasifikácie porastových štruktúr. Pri segmentácii vyššej hierarchickej úrovne je totiž možné hranice segmentov (obrazu) na snímke stotožnił s hranicami jednotlivých štruktúrnych prvkov, segmentov a typov porastov. Pri tematickom mapovaní a posudzovaní segmentov porastov sú podrobne zaznamenávané údaje o ich druhovej, priestorovej a vekovej štruktúre. Polohové zjednotenie vrstiev tematického mapovania sa zabezpečilo pomocou siete orientačných, referenčných a navigačných bodov zameraných meračskými GPS a v teréne viditel’ne označených. Pri digitálnej klasifikácii sú charakteristiky segmentov odvodzované zo spektrálnych, štruktúrnych a textúrnych charakteristík porastov zobrazených na snímkach, s využitím modelu reliéfu.

Základnou východiskovou pracovnou metódou použitou na vymedzenie (ohraničenie) skúmaných objektov - prvkov porastovej štruktúry, je segmentácia na 

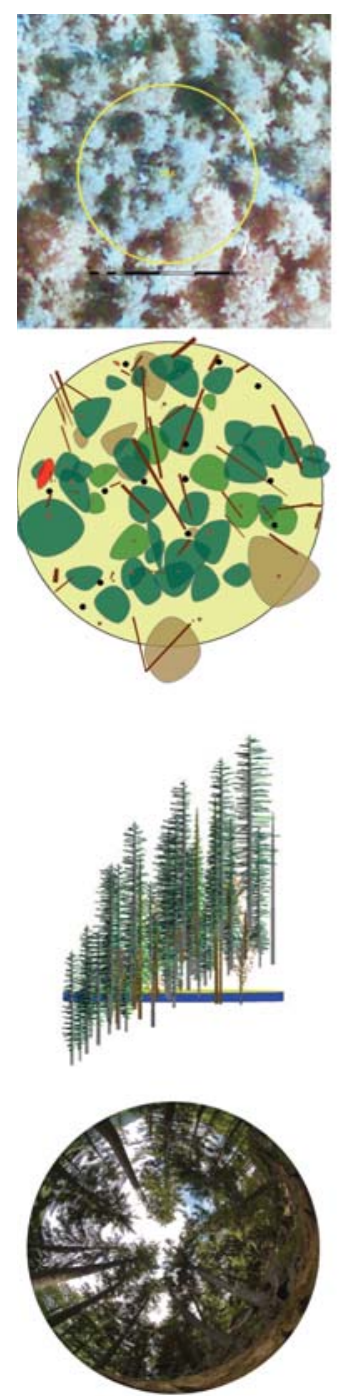

VX6
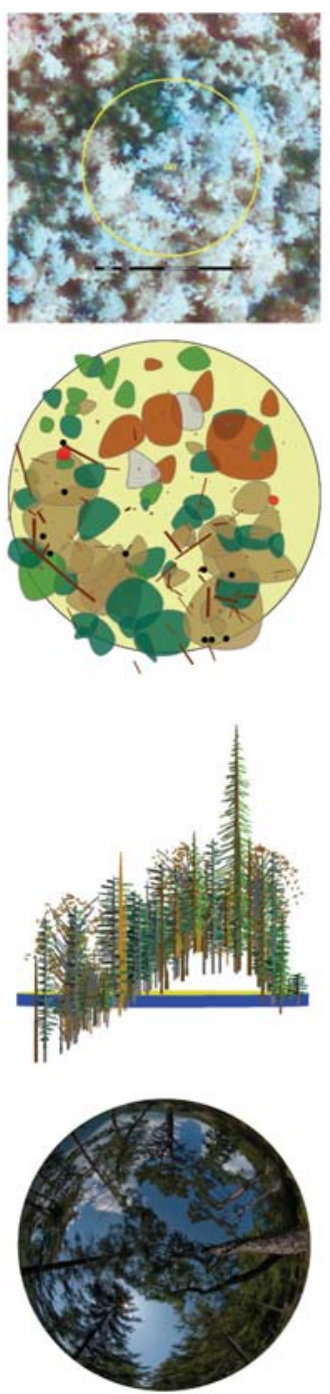

VX7
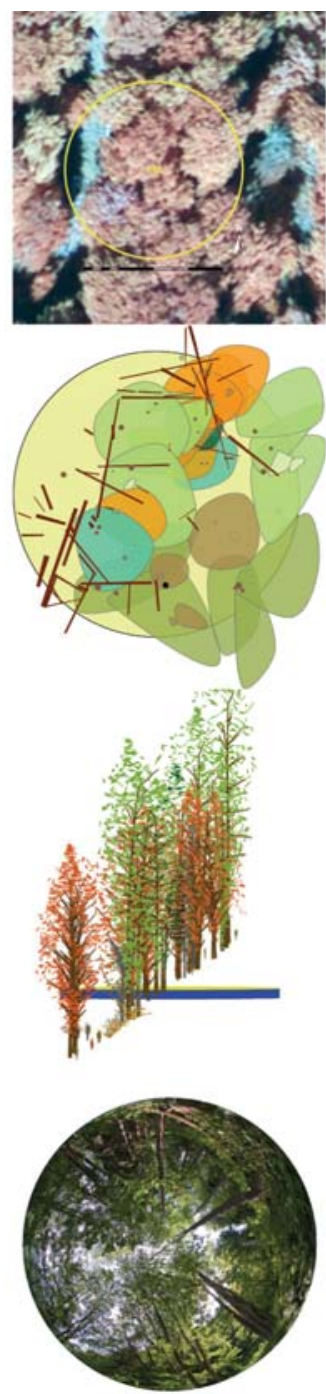

VX8
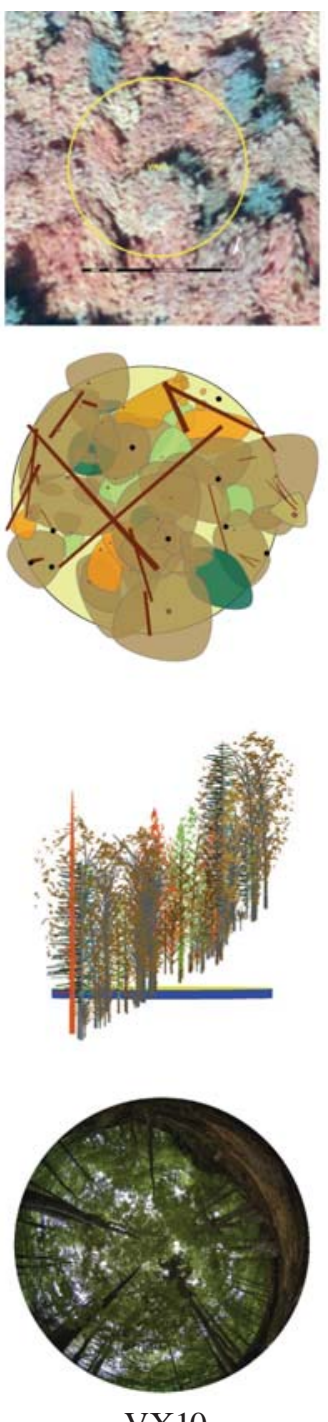

VX10
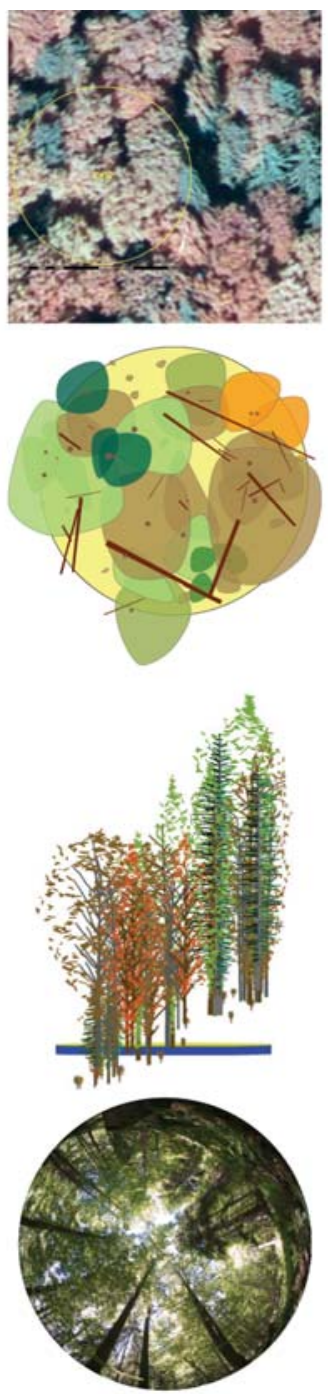

VX12

Obr. 8. Textúra a štruktúra porastov na výskumných plochách - ML Medvedia úboč

Fig. 8. Texture and structure of stands on research plots - ML Medvedia úboč

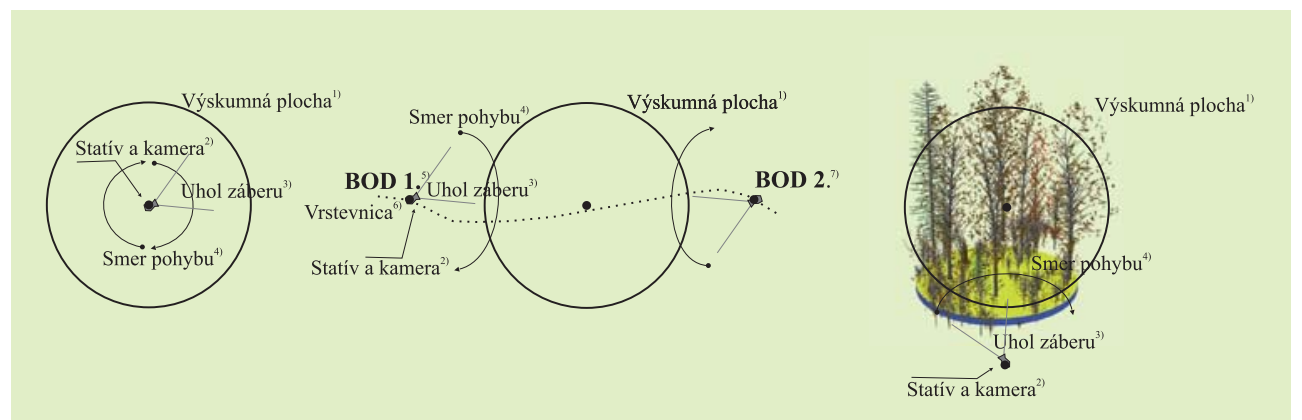

Obr. 9. Schéma štandardizovaného systému videozáznamov na výskumných plochách

Fig. 9. Scheme od standard video data system on research plots

${ }^{1)}$ Research plot, ${ }^{2}$ Stand and camera, ${ }^{3)}$ Angle, ${ }^{4}$ Direction, ${ }^{5)}$ Point 1, 6) Level line, ${ }^{7)}$ Point 2 


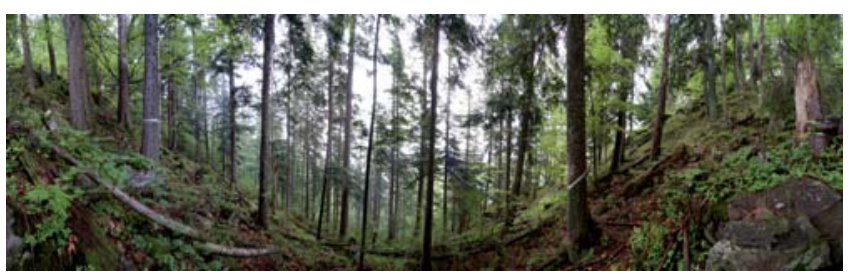

Obr. 10 a. Pozemná panoramatická $\left(360^{\circ}\right)$ snímka interiéru výskumnej plochy VX3 v spoločenstve slt Fagetum abietino-piceosum inf.; SPT - porasty jedle so smrekom a bukom; ML Medvedia úboč

Fig. 10 a. Panorama image of the research plot VX3 in Fagetum abietino-piceosum inf., SPT - fir stands with spruce and beech, ML Medvedia úboč
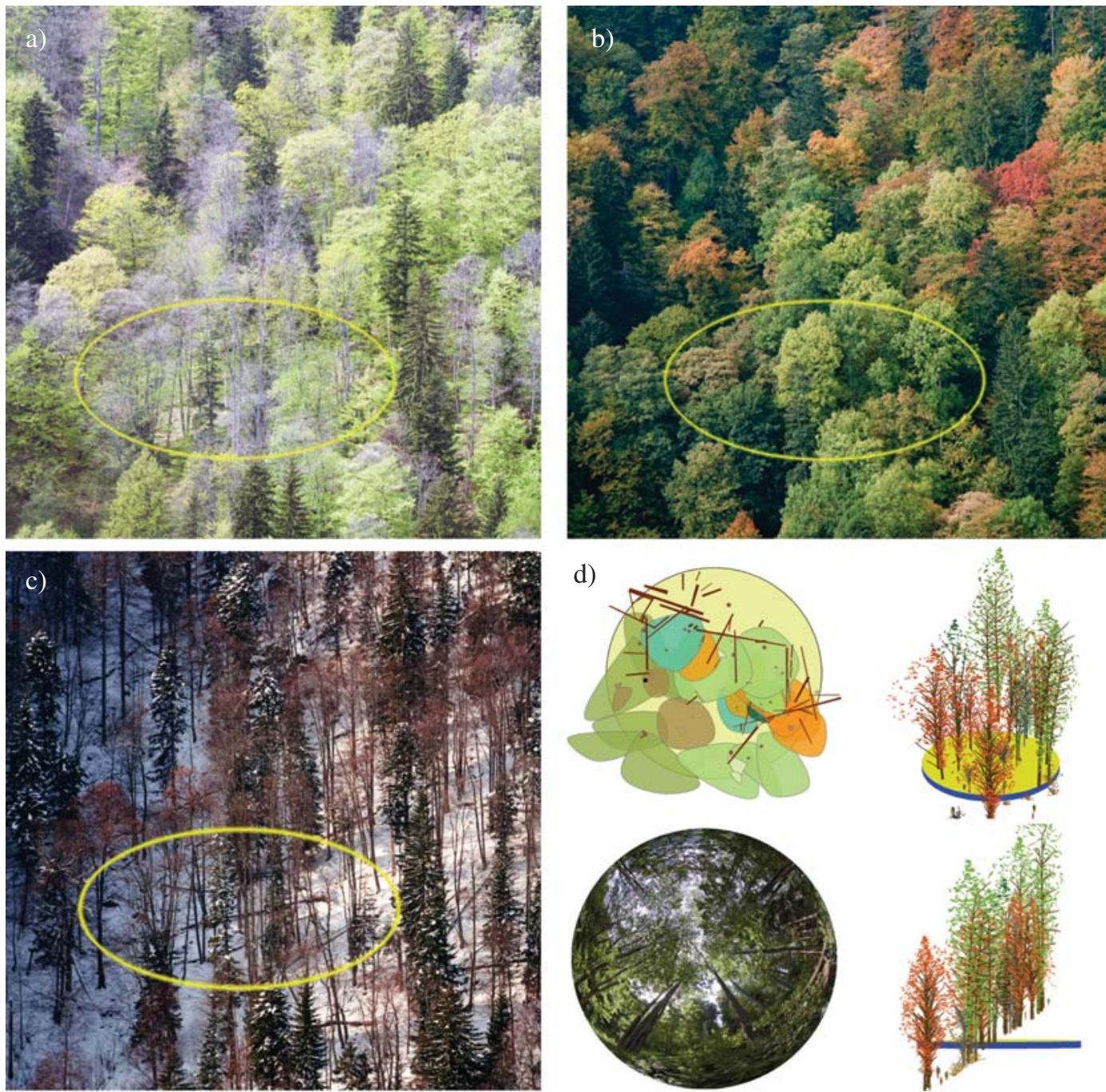

Obr. 11 a až c. Ukážka textúry porastu na ML Medvedia úboč (VP VX8) zachytená snímkami z protilahlého svahu v jarnom (29. 4. 2011), jesennom (8. 10. 2009) a zimnom období (10. 2. 2010). Velmi dobrá identifikovatel'noste až na úroveň jednotlivých stromov

Fig. $11 \boldsymbol{a}-\boldsymbol{c}$. Stand texture in ML Medvedia úboč (VP VX8) taken from the opposite slope in spring (29. 4. 2011 ), autumn (8. 10. 2009) and winter (10. 2. 2010). Highly identified on the level of individual trees

Obr. 11 d. Vizualizácia štruktúry výskumnej plochy VX8 porastu cenných listnáčov s bukom a jedlou v slt Fraxineto-Aceretum inf. prostredníctvom ArcGIS a SVS s hemisférickou snímkou korunovej sféry

Fig. 11 d. Visualisation of structure on a research plot VX8 in the stand of valuable broadleaves with beech and fir in FraxinetoAceretum inf. using ArcGIS and SVS with a hemispheric image of crown sphere 
multispektrálnych leteckých farebných snímkach z rokov 2008 (1. 9. 2008) a 2009 (23. 7. 2009), (obr. 12). Segmentáciu sme urobili pomocou softvéru Definiens Developer. V princípe ide o stratifikačný postup na základe farebných a tvarových charakteristík mapovaných a klasifikovaných objektov. Nastavenie parametrov segmentácie štruktúrnych prvkov porastov sme vykonali na základe poznatkov $\mathrm{z}$ terénnych pozorovaní a postupnými iteráciami a konfrontovaním s vybranými podrobnými charakteristikami z pozemných zisfovaní a meraní z výskumných plôch a popisovaných segmentov. Výrez zo segmentácie nad IRC snímkou z roku 2008 s lokalizáciou výskumných plôch uvádzame na obrázku 12. Vo finálnej fáze sme na ML o výmere 63 ha lokalizovali celkom 98 segmentov vyššej hierarchickej úrovne s priemernou výmerou 0,64 ha (max. 3,19 ha; min. 0,43 ha; variabilita $82 \%)$.

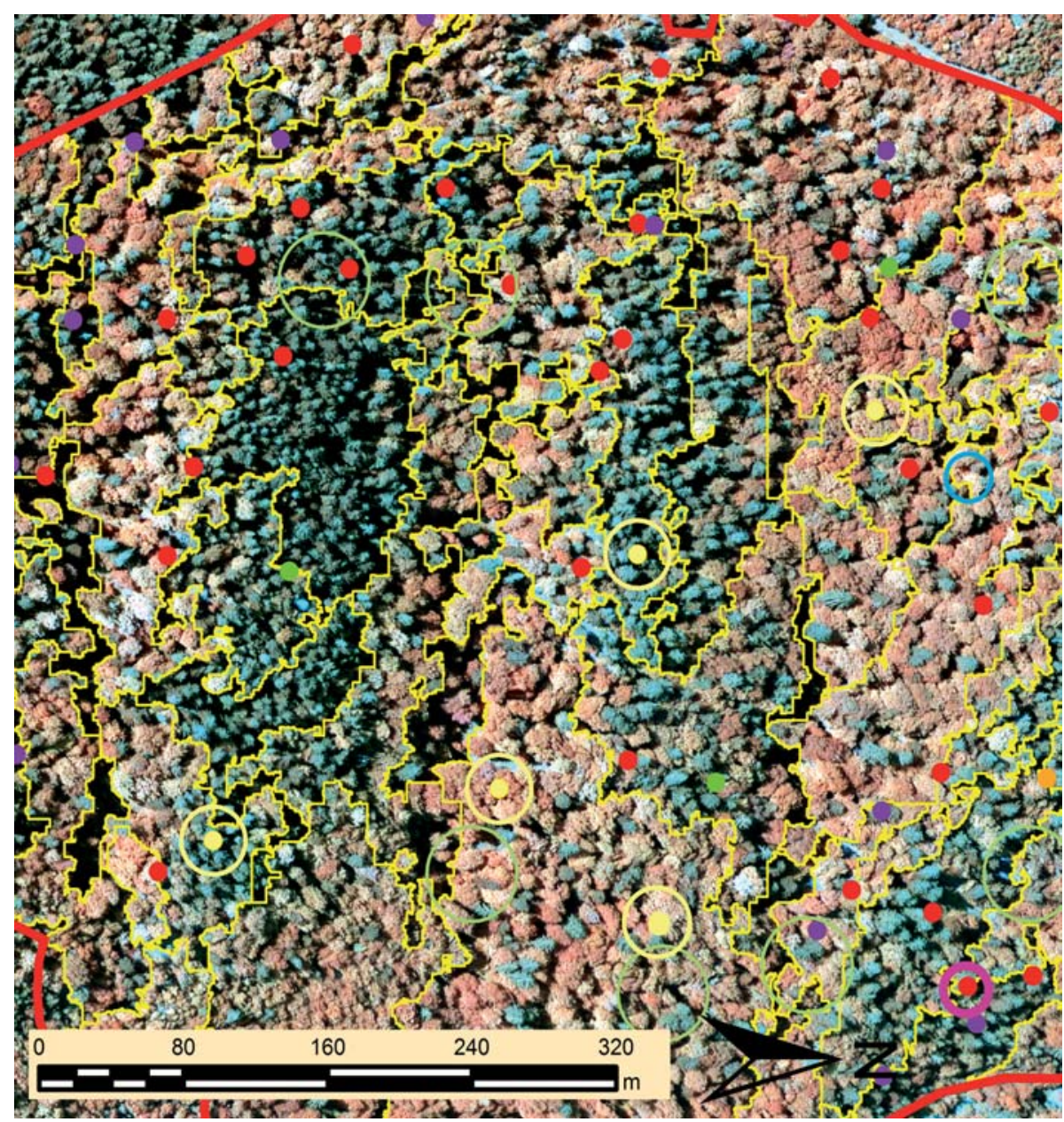

Obr. 12. Výrez zo segmentácie porastov na IRC leteckej ortofotosnímke z ML Medvedia úboč, urobená v rámci tematického mapovania a klasifikácie porastových štruktúr Fig. 12. Section of stand segmentation on IRC aerial ortho photo in ML Medvedia úboč taken in terms of thematic mapping and classification of stand structures

1949

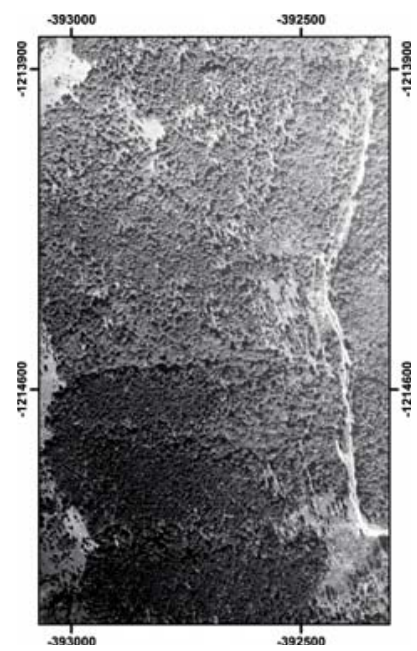

1971

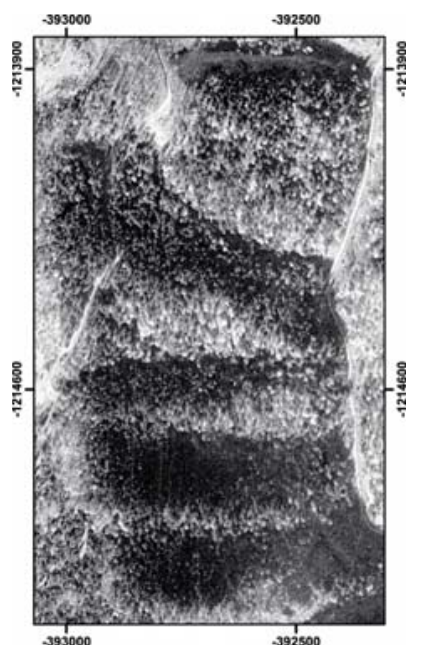

1992

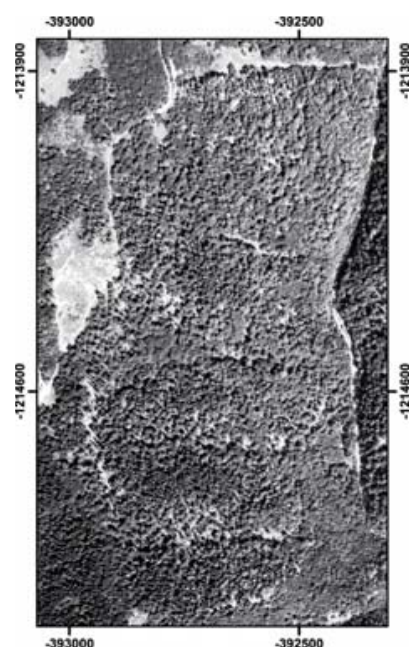

2009

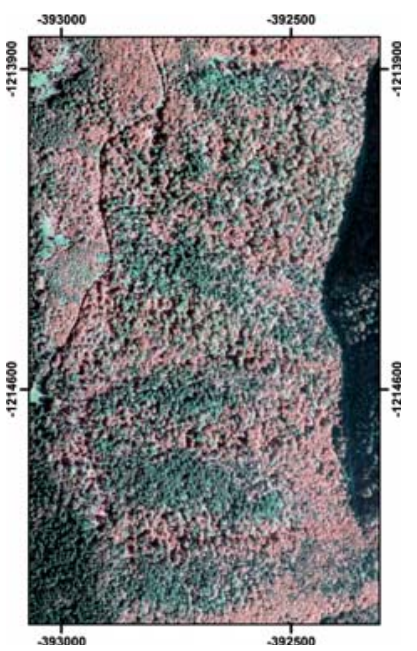

Obr. 13. Historické letecké meračské snímky sú využitel’né pri interpretácii tendencií a trendov vývoja porastových textúr v porovnaní s aktuálnym stavom textúr na multispektrálnej leteckej snímke (ML Medvedia úboč)

Fig. 13. Historic aerial photos can be used in interpreting the tendencies and development trends of stand textures in comparison to the current condition of textures in a multispectral aerial image (ML Medvedia úboč) 


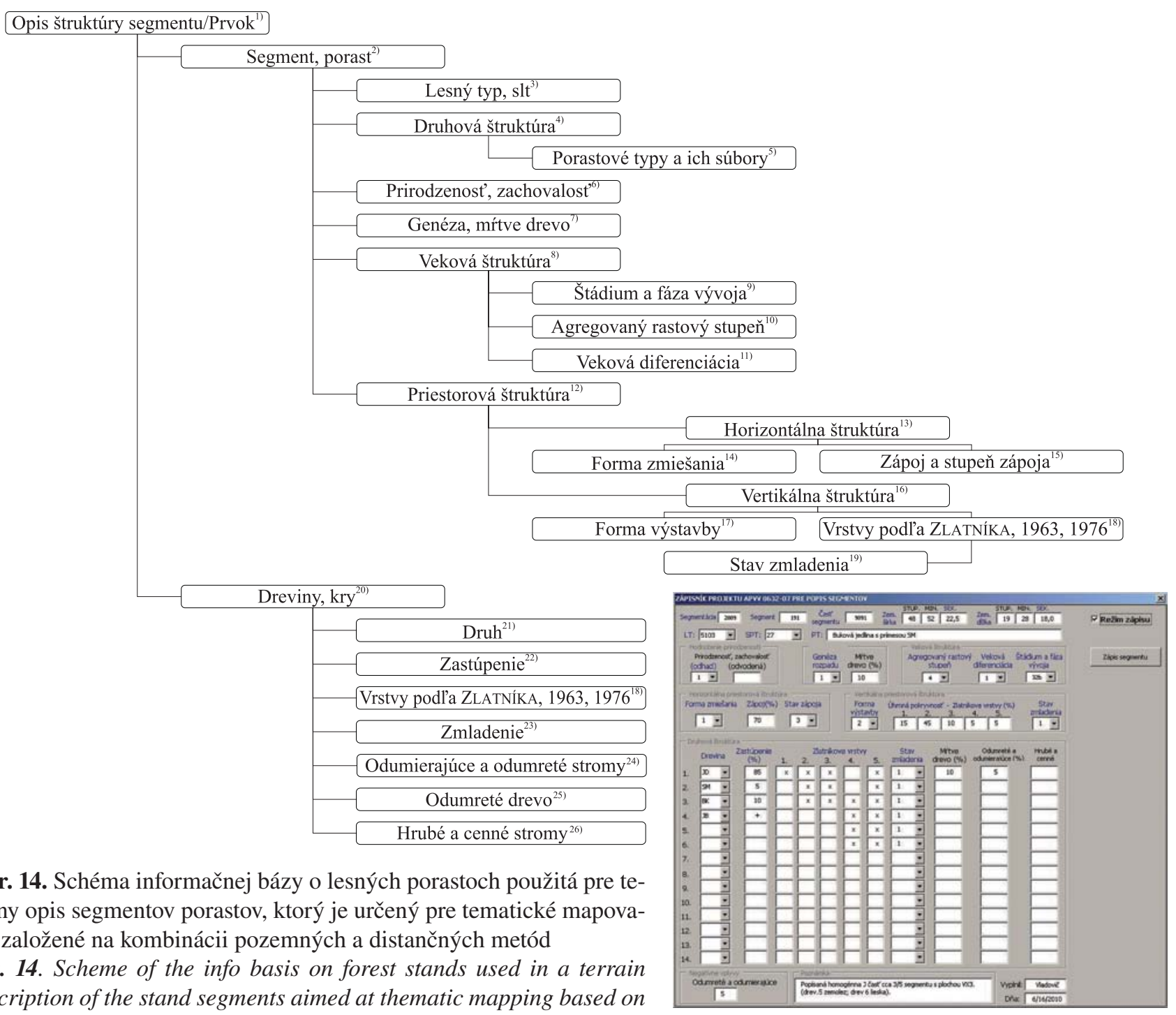

Obr. 14. Schéma informačnej bázy o lesných porastoch použitá pre terénny opis segmentov porastov, ktorý je určený pre tematické mapovanie založené na kombinácii pozemných a distančných metód

Fig. 14. Scheme of the info basis on forest stands used in a terrain description of the stand segments aimed at thematic mapping based on a combination of ground-based and distant methods

${ }^{1)}$ Describtion of the segment structure/element, ${ }^{2}$ Stand segment, ${ }^{3)}$ Forest type, ${ }^{4}$ Species structure, ${ }^{5}$ Stand types and their sets, ${ }^{6}$ Naturalness, preservation, ${ }^{7}$ Genesis, dead wood, ${ }^{8}$ Age structure, ${ }^{9}$ Development stage and phases, ${ }^{10}$ Aggregated age stage, ${ }^{11}$ Age differentiation, ${ }^{12}$ Spatial structure, ${ }^{13}$ Horizontal structure, $\left.{ }^{14}\right)$ Form of the mixture, ${ }^{15}$ Canopy, ${ }^{16}$ Vertical structure, $\left.{ }^{17}\right)$ Form of the construction, ${ }^{18}$ Layers according to ZLATNí, 1963, 1976, $\left.{ }^{19}\right)$ Regeneration condition, ${ }^{20}$ Tree species, shrubs, ${ }^{21}$ Type, ${ }^{22)}$ Representation, ${ }^{23)}$ Regeneration, ${ }^{24}$ Dying and dead trees, ${ }^{25}$ Dead wood, ${ }^{26}$ High diameter and valuable trees

\subsubsection{Terénny opis a klasifikácia segmentov lesných porastov}

Pri tematickom mapovaní a posudzovaní porastových štruktúr sme vychádzali z nasledovných zásad:

- Územie primerane rozdelit, stratifikovat na základné jednotky, segmenty - štrukturálne prvky, resp. najnižšie pomocné mapovacie jednotky vhodné pre opis a klasifikáciu (posudzovanie) štruktúry porastu (resp. spoločenstva).

- Racionalizovat stratifikačný postup efektívnou, primerane presnou technológiou na lokálnej alebo regionálnej úrovni (uplatnenie DPZ a GIS prístupov).

- Preferovai geografický prístup k posudzovaniu územia.

- Efektívne uplatnit poznatkové bázy a štrukturálne modely.
- Systém budovat ako otvorený, iteratívny, stavebnicový, s možnostou spätných väzieb aj opätovných korekcií.

- Dosiahnue kompatibilitu systému s možnostou budovania vyšších územných (priestorových) jednotiek zohladňujúcich tzv. širšie priestorové súvislosti mapovania a posudzovania.

Na modelových lokalitách sme podrobne opísali vybrané segmenty, a to aj na základe kalibrácie dát vykonanom na pomerne vysokom počte (10) podrobne biometricky meraných výskumných plôch technológiou FieldMap. Išlo najmä o zabezpečenie empirického materiálu pre podporu rozhodovania, nastavenie, odladenie a overenie systému tematického mapovania a posudzovania porastových štruktúr. Nadviazali sme pri- 
tom na naše poznatky a publikované výsledky výskumu z oblasti 7. smrekového vs. ML sme orientovali do stanovištne aj štrukturálne velmi pestrého a náročného terénu nachádzajúceho sa v 5 . jedlovo-bukovom vs. Na kontaktných lokalitách 6. smrekovo-bukovo-jedlového vs, 4. bukového vs boli vyššie uvedené postupy tiež použitel’né a overené a nezaznamenali sme nezrovnalosti ani pri ich uplatňovaní v podhorských oblastiach. Celkovo bolo na modelovej lokalite o výmere 63 ha klasifikovaných 98 segmentov porastov.

$\mathrm{Na}$ obrázku 14 prezentujeme schému informačnej bázy o lesných porastoch použitú v terénnych zápisníkoch pre opis porastov. Segment porastu je nositelom základných informácií o štruktúre a textúre porastu. Je zároveň základnou priestorovou jednotkou používanou pre prepojenie s poznatkovými bázami.

Každému segmentu porastu bolo priradené poradové číslo a v teréne sa posúdila správnosê vymedzenia segmentu a prípadná potreba jeho úpravy (spresnenie ohraničenia, rozdelenie a pod.). V miestach vykonaného záznamu sme zistili zemepisné súradnice. $Z$ podrobného typologického mapovania segmentovou metódou sa prevzal, príp. i overil lesný typ. Opisované spoločenstvo sme zaradili do porastového typu a súboru porastových typov. Odhadli sme stupeň zachovalosti (prirodzenosti) a stability porastu, (genézu jeho prípadného rozpadu) a podiel odumretého dreva. Vekovú štruktúru porastu sme opísali na základe zaradenia drevinovej zložky do vývojového štádia a fázy a tiež do tzv. agregovaného rastového stupňa. Zároveň sme na základe hrúbkového a výškového rozrôznenia porastu odhadli mieru jeho vekovej diferenciácie. Priestorovú výstavbu porastov sme hodnotili prostredníctvom opisu horizontálnej a vertikálnej štruktúry. Pri opise horizontálnej štruktúry sme sa zamerali na formu zmiešania, charakter porastového zápoja a jeho stupeň. Pri opise vertikálnej štruktúry porastov sme hodnotili formu výstavby, odhadli pokryvnosé porastových vrstiev podla ZLATNíKa (1963, 1976) a osobitne sme posúdili stav prirodzeného zmladenia. Odhadli sme aj podiel odumretých a odumierajúcich stromov ako nepriamy indikátor vitality, príp. zdravotného stavu porastu (stupeň poškodenia).

Druhovú štruktúru drevinovej a krovitej zložky sme opísali samostatne. Odhadli sme zastúpenie drevín, príslušnosî k vrstvám podla ZlatníKa (1963, 1976), stav zmladenia, podiel odumierajúcich a odumretých jedincov, podiel odumretého dreva a výskyt hrubých a cenných jedincov.

Na základe zistených údajov môžeme konštatovat', že v aktuálnom drevinovom zložení v modelovej lokalite prevláda súbor porastových typov (SPT) jedlové bučiny s plošným podielom $48 \%$ s prevažujúcim porastovým typom jedlové bučiny s cennými listnáčmi. Nasleduje SPT smrekovo-jedlové bučiny, s takmer $21 \%$ plošným podielom, SPT porasty jedle s listnáčmi (11,9\%), SPT bučiny s cennými listnáčmi (6,4\%), SPT cenné list- náče a ich zmesi (4,8\%) a SPT smrekovo-bukové jedliny (4,3\%). Z hladiska vývojového štádia (vekovej štruktúry) prevažujú porastové štruktúry v štádiu optima, ktoré zaberajú $69 \%$, z toho vo fáze sieňovej výstavby je 43,1\% a vo fáze starnutia $25,9 \%$ výmery porastov. Do štádia dorastania sme zaradili vyše $28,1 \%$ porastových štruktúr a do štádia rozpadu takmer $2 \%$ porastov. Z hladiska typizácie na úrovni agregovaných rastových stupňov (ARS) až na 91,4 \% územia sa vyskytujú hrubé a velmi hrubé kmeňoviny. Stredné a tenké kmeňoviny sa nachádzajú na 5,6\% výmery ML. Do skupiny velmi silne vekovo diferencovaných porastových štruktúr (s rozdielom veku nad 70 rokov) sme zaradili takmer $81 \%$ posudzovaných segmentov a do skupiny stredne vekovo diferencovaných porastov (s vekovou diferenciáciou 20 až 70 rokov) necelých $16 \%$ segmentov.

Prevažujúcou formou zmiešania porastov je skupinkovitá forma $(0,03$ až 0,1 ha), ktorá sa vyskytuje na 26,5 \% výmery ML. Hlúčikovitá forma zmiešania ( $<0,03$ ha) sa vyskytuje na 22,4 \% ML a jednotlivé zmiešanie bolo zaznamenané na $18,1 \%$ výmery ML.

Prirodzené zmladenie plne zodpovedajúce porastovým podmienkam sa zistilo na $94 \%$ posudzovanej plochy, zatial' čo minimálne zmladenie sa zistilo na 2,5\% výmery ML.

\section{Diskusia a závery}

Posudzovanie štruktúry a textúry segmentov lesa vo vzájomných širších priestorových súvislostiach sa vykonáva na báze zjednocovania geografických (priestorových) a atribútových informácií v prostredí ArcGIS, pričom vlastná klasifikácia je systémovo naviazaná na priebežne vyhotovované poznatkové bázy a modely priaznivého stavu jednotlivých spoločenstiev (VLADOVIČ et al., 2011).

Aktuálny stav lesného spoločenstva závisí od priestorového usporiadania a stavu štrukturálnych prvkov a typov nachádzajúcich sa v posudzovanom území. Stav lesných spoločenstiev reprezentujú štrukturálne prvky, ktoré hodnotíme v prostredí GIS vo väzbe na vyššie lesnícko-typologické jednotky a segmenty lesných typov. Lesnícko-typologické jednotky vyjadrujú jednotu ekotopu s biocenózou nachádzajúcou sa v klimaxovom sukcesnom štádiu (vyjadrujú stanovištný potenciál posudzovaných spoločenstiev). Dôležitou podmienkou vhodnosti uplatnenia uvedenej metódy je zjednotenie mierky - reálnej podrobnosti zachytenia klasifikovaných objektov. Vel'mi dôležitým aspektom klasifikácie je zohladnenie tzv. priestorových súvislostí, t. j. ako sú štruktúrne prvky vzájomne usporiadané, aká je ich vel'koste, tvar a aký je výskyt a rozmiestnenie tzv. rizikových a kritických prvkov a typov porastových štruktúr (VLADOvič et al., 1999; Vladovič, Bucha, 1999; Vladovič, 2003, 2004). Systém posudzovania teda vychádza z priestorového porovnania súčasného a potenciálneho stavu lesných spoločenstiev. Prepojený je na poznatkové bázy a štruktu- 


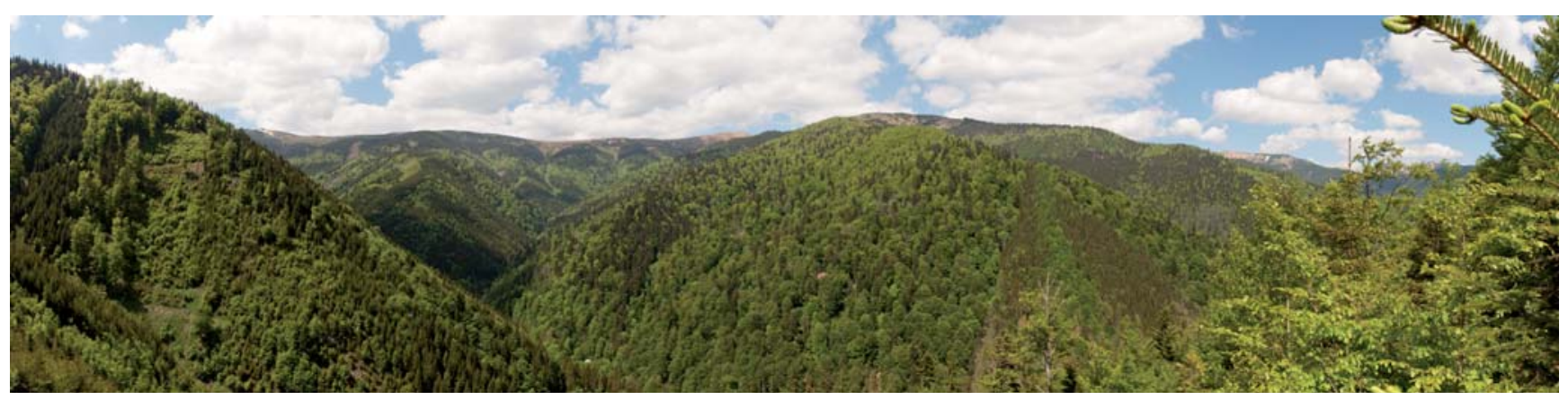

Obr. 15. ML Pod Latiborskou hol’ou - panoráma vyhotovená z protilahlého svahu (21. 5. 2009)

Fig. 15. ML Pod Latiborskou holou - panorama image taken from the opposite slope (21. 5. 2009)

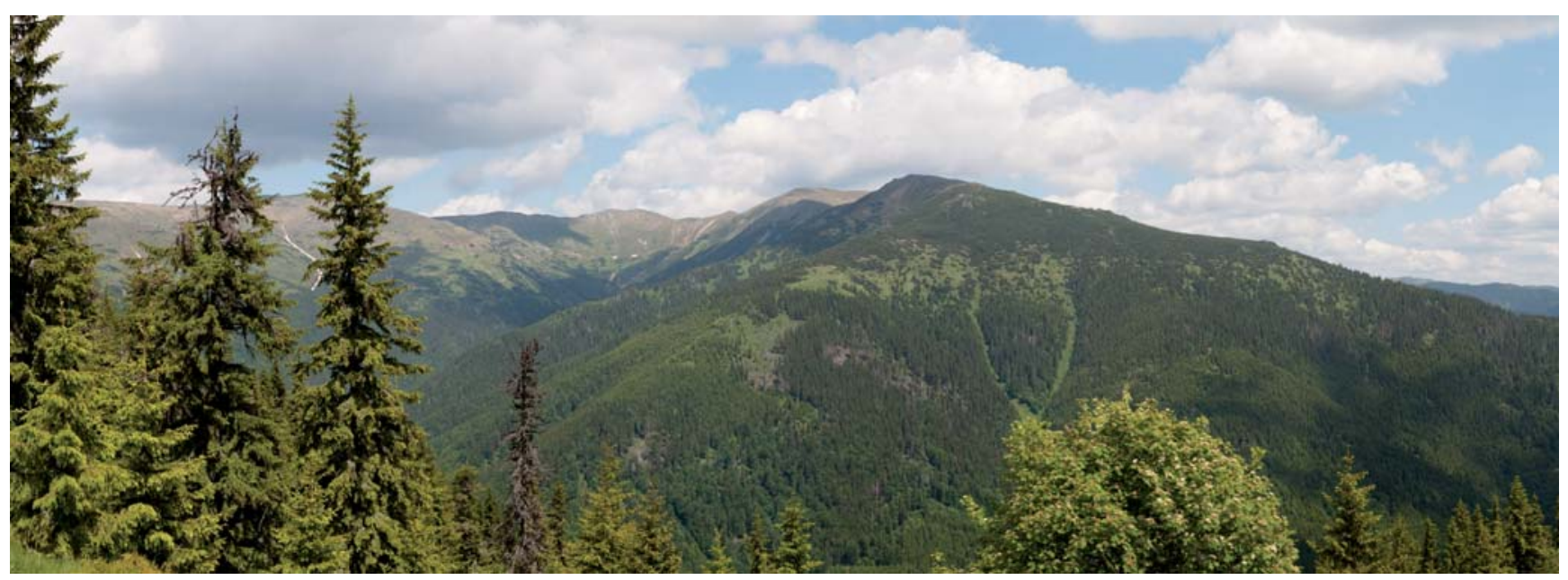

Obr. 16. ML Široký úplaz - panoráma vyhotovená z protil’ahlého svahu (17. 6. 2009); v smrekovom vegetačnom stupni vidię kalamitný rozpad, odsuny porastových stien a podkôrnikové ohniská

Fig. 16. ML Široký úplaz - panorama image taken from the opposite slope (17. 6. 2009); calamitous decline in the spruce vegetation zone, movement of stand boundaries and bark beetle epicentres

rálne modely a zohladňuje širšie priestorové súvislosti výskytu lesov v krajine.

Vývoj lesnatosti a textúr lesných spoločenstiev nachádzajúcich sa na modelových lokalitách sme zdokumentovali časovými radmi historických leteckých snímok (v poslednom období i časovými radmi satelitných scén) a zobrazením stavu lokalít z historického vojenského mapovania.

Predkladaná práca je tiež príspevkom k posudzovaniu stavu lesných biotopov. Priaznivý stav európsky významných lesných biotopov zahrnutých do siete NATURA 2000 definoval a na báze systému kritérií a indikátorov vyhodnotil kolektív špecialistov na lesné ekosystémy v práci PoLÁK, SAXA et al. (2005). V práci uvádzajú prehlad základných kritérií a indikátorov používaných pre hodnotenie stavu lesných biotopov, ich definície, koncept ich hodnotenia pomocou číselných kvantifikátorov, tabul'ky pre hodnotenie priaznivého stavu lesných biotopov a rámcové manažmento- vé opatrenia pre zachovanie ich priaznivého stavu. Už v tejto práci sa využili poznatky, ktoré sme získali pri výskume štruktúry lesov, ako aj výsledky špeciálnych prieskumov a typologického mapovania. Išlo o syntetizujúci rámcový materiál, orientovaný len na biotopy európskeho významu. V diskutovanej teoreticky koncipovanej práci nebol priestor na detailné a konkrétne riešenie a prezentovanie inovatívnych prístupov pri tematickom mapovaní a posudzovaní porastových štruktúr lesných spoločenstiev na konkrétnych príkladoch. Neriešili sa lesné biotopy a územia nachádzajúce sa mimo siete NATURA 2000.

Nami predkladaná práca vypíňa uvedený priestor prostredníctvom uplatnenia inovatívnych prístupov. Prezentované sú v nej podrobné prístupy v tematickom mapovaní a posudzovaní štruktúry lesov na báze uplatnenia kombinácie distančných a pozemných metód a postupov. Tieto sme na konkrétnych modelových územiach a lokalitách aj prakticky overili. 
Prezentované poznatky (výsledky a prístupy) môžu úspešne využit aj špeciálne prieskumy lesa, napr. pri tzv. „Komplexnom zistovaní stavu lesov“ v rámci prieskumov NLC v Ústave pre hospodársku úpravu lesov (ÚHÚL). Prínosom sú aj poznatky postupne zverejňované v poznatkových bázach a štrukturálnych modeloch. Vel'mi praktickým a žiaducim prínosom sú aj prezentované možnosti detailnejšieho vymedzenia typov, prvkov a segmentov aktuálnej lesnej vegetácie na mapách $\mathrm{s}$ väčšou presnostou (podrobnostou) ako je tzv. porastové členenie (JPRL). V práci sme uplatnili dnes už štandardne dostupné materiály, podklady a technológie DPZ.

Nadviazali a prehíbili sme tak na poznatky Buchu, VladoviČA, RAŠIHO (2010, in FerANeC et al., 2010), ktorí v Nízkych Tatrách aj v d’alších oblastiach Slovenska uplatnili metódy klasifikácie drevinového zloženia, štruktúry a zdravotného stavu lesov na báze DPZ aj ich uplatnenia v hospodársko-úpravníckych prácach (Bucha et al., 2010).

$\mathrm{V}$ posudzovanej modelovej lokalite Medvedia úboč nachádzajúcej sa v Lomnistej doline (Nízke Tatry) sme zaznamenali a prezentovali progresívne vývojové tendencie štruktúry lesných porastov v rámci malého vývojového cyklu prírodných spoločenstiev 5 . jedlovo-bukového vs a dynamiku vývoja porastových medzier. Zistili a zdokumentovali sme relatívne dynamický proces samovývoja porastov na silne exponovanom a vel'mi rozrôznenom reliéfe terénu. Na ML je zabezpečená vývojová samostatnosí s priaznivým stavom druhovej diverzity.

Takmer celé územie ML Medvedia úboč bolo tiež osobitne mapované a klasifikované ako pralesové územie (Obrštín) v rámci projektu Ochrana pralesov Slovenska (JAsík et al., 2010). Uvedená územná klasifikácia je v zásade v súlade aj s výsledkami nášho tematického mapovania a klasifikácie porastových štruktúr. V našej práci sme pracovali na detailnejšej úrovni, s exaktným empirickým materiálom a výsledkami z výskumných plôch a z podrobnejšej plošnej klasifikácie štrukturálnych segmentov.

Vyššie uvedené prístupy a princípy posudzovania porastových štruktúr sme overili aj na modelovej lokalite Pod Latiborskou holou (obr. 15) a dospeli sme k vymedzeniu územia, ktoré je v prevažujúcej časti totožné s hranicami rovnomennej národnej prírodnej rezervácie (NPR). Pre územie je charakteristická pestrá a maloplošná mozaika porastových štruktúr a vysokým podielom ekologicky stabilných lesných ekosystémov 5. jedlovo-bukového a 6. smrekovo-bukovo-jedlového vs (VLADovič et al., 2007). Prezentované prístupy sa aj na tejto ML v plnej miere potvrdili, čo sme tiež podrobne zdokumentovali na 14 výskumných plochách. Podrobné biometrické merania technológiou FieldMap sme tu vykonali na 9 VP. Výsledky sú tiež súčastou katalógu štrukturálnych modelov (VLAdovič et al., 2011).

Obdobné prístupy sme prezentovali a preverili aj v modelovej lokalite Široký úplaz (obr. 16), s prevahou spoločenstiev 7. smrekového a 8 . kosodrevinového vs.
Pre ML sme odvodili krátkodobú aj strednodobú ekologickú stabilitu územia a zároveň sme vypracovali prognózu vývoja porastových štruktúr a textúr, najmä s dôrazom na výskyt a priestorové šírenie tzv. rizikových a kritických typov a prvkov porastových štruktúr (Vladovič, 2000, 2003, 2005). S odstupom vyše desiatich rokov možno konštatovał, že sa naše prognózy na ML Široký úplaz naplnili, najmä čo sa týka negatívneho vývoja a destabilizácie porastových štruktúr. Išlo najmä o synergický efekt vplyvu škodlivých činitelov, odsun otvorených a exponovaných porastových okrajov, vplyv vetra, nálet podkôrneho hmyzu, vplyv snehu, lavín a d’alšie faktory. Významným negatívnym faktorom bolo šírenie tzv. podkôrnikovej kalamity. Ohniská sa rozšírili aj do vel'mi dobre štruktúrovaných prírodných lesov.

Vyššie uvedené výsledky nás utvrdzujú v presvedčení, že vo výskume i v realizácii posudzovania porastových štruktúr je potrebné kontinuálne pokračovat. Význam spočíva nielen v prehlbovaní a rozvoji poznania, ale aj d’alšieho praktického riešenia a navrhovania opatrení v prospech dosiahnutia (obnovenia) a dlhodobej udržatelnosti priaznivého stavu a ekologickej stability lesných ekosystémov v krajine. To je možné dosiahnư systémovým riešením problematiky posudzovania stavu a vývoja lesov prostredníctvom ich druhovej, priestorovej a vekovej štruktúry so zohladnením širších priestorových súvislostí výskytu lesov v krajine.

Predkladaná práca predstavuje aj inovatívne prístupy $\mathrm{k}$ riešeniu problematiky tematického mapovania a posudzovania štruktúry a textúry lesných spoločenstiev v kontexte zistovania a posudzovania stavu a vývoja lesných spoločenstiev. Zlepšenie metodologických prístupov spočíva najmä v uplatnení kombinácie distančných a pozemných metód a uplatnení materiálov a technológií najmä leteckého, ale aj satelitného DPZ a novších metód spracovania obrazu na báze jeho segmentácie. Praktický význam a využitel'nosé vidíme aj pri mapovaní lesných biotopov, a to v možnosti detailnejšej lokalizácie hraníc areálov aktuálnej vegetácie na báze DPZ a metódy segmentácie posudzovaného územia. Prínosom je najmä fakt, že prezentované prístupy boli overené na viacerých modelových lokalitách a v rôznych vegetačných stupňoch, s možnostou zovšeobecnenia pre celé spektrum lesných spoločenstiev Slovenska.

\section{Pod'akovanie}

Táto práca bola podporená Agentúrou na podporu výskumu a vývoja na základe zmluvy č. APVV-0632-07 $v$ rámci riešenia projektu: Výskum metód klasifikácie a štrukturálnych modelov priaznivého stavu lesných ekosystémov Slovenska - Hodnotenie stavu a vývoja lesov $v$ krajine s podporou DPZ (40\%-ný podiel).

$V$ rámci riešenia projektu: Centrum excelentnosti pre podporu rozhodovania v lese a krajine, aktivita 3.4, ASFEU, ITMS: 26220120069, v rámci operačného progra- 
mu Výskum a vývoj, spolufinancovaný zo zdrojov Európskeho fondu regionálneho rozvoja (40\%-ný podiel).

A v rámci operačného programu Výskum a vývoj pre projekt: Integrovaný systém pre simuláciu odtokových procesov, aktivita 2.1, ASFEU, ITMS: 26220220066, spolufinancovaný zo zdrojov Európskeho fondu regionálneho rozvoja (20\%-ný podiel).

\section{Literatúra}

Bucha, T., Vladovič, J., Juriš, M., Barka, I., 2010: Aplikácie dial'kového prieskumu Zeme využitelné v prácach HÚL. In: BoRTEL, S., BAVlšík, J. (eds.): Súčasnost’ a budúcnost' hospodárskej úpravy na Slovensku: Zborník príspevkov z odborného seminára, Zvolen 27. januára 2010, Zvolen: Národné lesnícke centrum, 2010, s. 73-82.

Feranec, J., Bucha, T., Csaplár, J., Hefty, J., Jurašek, M., KaňÁk, J., Kudela, K., Machková, N., SvičEK, M., VoJtko, R., Scholtz, P., Nováková, M., Szöcsová, I., Raši, R., Vladovič, J., Zeman, M., FINĎo, S., 2010: Slovensko očami satelitov. 1. vyd. Bratislava : VEDA, vydavatel'stvo Slovenskej akadémie vied, $264 \mathrm{~s}$.

JAsík, M., VysokÝ, J., PoLÁK, P., TuŽINSKÝ, J. a kol., 2010: Ochrana pralesov Slovenska. Dostupné na internete: http://www.fscslovakia.sk/content/view/127/83/

KorPec, Š., 1989: Pralesy Slovenska. Bratislava: Veda, 332 s.

McGaughey, R., J., 2002: Stand Visualisation System - SVS, USDA Forest Service, Pacific Northwest Research Station; Dostupné na internete: http://forsys.cfr.washington.edu/winsvs/svs.html

Moravčík, M. et al., 2002: Hospodárska úprava horských lesov z hladiska ekologizácie lesného hospodárstva. Záverečná správa za čiastkovú úlohu VTP 2730-06. Zvolen: Lesnícky výskumný ústav Zvolen, 2002, $217 \mathrm{~s}$.

— a kol., 2005: Zásady a postupy hospodárskej úpravy a obhospodarovania horských lesov smrekového vegetačného stupňa. Lesnícke štúdie, č. 58, Zvolen: Lesnícky výskumný ústav Zvolen, s.

Polák, P., SaXa, A. (eds.), 2005: Priaznivý stav biotopov a druhov európskeho významu. Banská Bystrica: ŠOP SR, 736 s.

Vladovič, J., Bucha, T., 1999: Tematické mapovanie porastových typov ako nástroj na odvodenie poznatkov o vertikálnom a priestorovom rozšírení lesných spoločenstiev Lomnistej doliny. Lesnícky časopis - Forestry Journal, 45(5-6): 371-387.

—, 2003: Oblastné východiská a princípy hodnotenia drevinového zloženia a ekologickej stability lesov Slovenska. Lesnícke štúdie, č. 57, Bratislava, Príroda, 160 s.

—, 2004: Poznatky z výskumu štruktúry a ekologickej stability horských lesov v Nízkych Tatrách. In: Príroda Nízkych Tatier 1. Banská Bystrica, SNAPANT, s. 315-328.

—, PôBIš, I., Frič, L., 2004: Výskum, tematické mapovanie a posudzovanie štruktúry lesných spoločenstiev v Nízkych Tatrách. In: Príroda Nizkych Tatier 1. Banská Bystrica, SNAPANT, s. 329-331.

-, Merganič, J., Pavlenda, P., GréK, J., Ištoňa, J., Rizman, I., KRIŽová, E., Ujházy, K., PôBiš, I., Valach, L., 2005: Pracovné postupy terénnych prác obnovy typologických reprezentatívnych plôch. Zvolen: LVÚ Zvolen, $58 \mathrm{~s}$.

—, 2005: Tematické mapovanie typov porastovej štruktúry s uplatnením DPZ a GIS. In: MoRavčík, M., 2005: Zásady a postupy hospodárskej úpravy a obhospodarovania horských lesov smrekového vegetačného stupňa. Lesnícke štúdie, 58, Zvolen: Lesnícky výskumný ústav Zvolen, s. 103-107.

—, Máliš, F., Vodálová, A., 2007: Poznatky z výskumu dynamiky, ekologickej stability a diverzity horských lesných ekosystémov v Nízkych Tatrách In: KRIžová, E., UjHÁzy, K. (eds.) 2007: Dy- namika, stabilita a diverzita lesných ekosystémov. Zvolen: Technická univerzita, s. 59-66.

—, PôBIš, I., VodÁlovÁ, A., Frič, L., 2007: Z výskumu diverzity porastových štruktúr v PR Martalúzka v Nízkych Tatrách. In: KRIŽová, E., UsнÁzy, K. (eds.), 2007: Dynamika, stabilita a diverzita lesných ekosystémov, Zvolen: Technická univerzita, s. 287-289.

—, Frič, L., MÁliš, F., OndRuš, M., 2007: Štrukturálna diverzita a ekologická stabilita lesných ekosystémov v NPR Pod Latiborskou holou. In: KRIŽovÁ, E., UsHÁzy, K. (eds.): Dynamika, stabilita a diverzita lesných ekosystémov, Zvolen: Technická univerzita, s. 283-285.

—, VodÁlová, A., LuPTÁK, I., BARKA, I., Frič, L'., MEŇUǓ, M., 2009: Posudzovanie štruktúry lesa s uplatnením diastančných a pozemných metód. In: Hrubá, V., ŠTYKaR, J. (eds.): Geobiocenologie a její aplikace v krajině : Sborník referátů z geobiocenologické konference. Brno: Mendelova zemědělská a lesnická univerzita v Brně, s. 204-205. (Geobiocenologické spisy, svazek č. 13).

— et al., 2011: Štruktúra a diverzita lesných ekosystémov na Slovensku. Zvolen, Národné lesnícke centrum - Lesnícky výskumný ústav Zvolen, $252 \mathrm{~s}$.

Zlatník, A., 1953: Fytocenologie lesa. Praha: SPN, 495 s.

—, 1963: Fytocenologie lesa. část I. všeobecná. Učební texty LF VŠZ v Brně, Praha: SPN, 372 s.

—, 1976: Lesnická fytocenologie, Praha: SZN, 495 s.

\section{Summary}

The paper addresses the issue of thematic mapping and assessment of structures and textures of the forest stands based on a combination of distance and ground-based methods using remote sensing and GIS. Figure 1 shows framework scheme of the methodological approach. We present results of the thematic mapping of sets of stand types in the modelling area Lomnistá Valley in Low Tatras (1,623 ha) in reference to our previous research (Fig. 3). In the paper we present results on mapping of structural types and segments, structure classification and ecological stability of mountain forests in the modelling areas Konštiaky, Široký úplaz, Martalúzka - Byčiarky in the Low Tatras of over 270 ha (Fig. 4). We present the actual innovative approaches and methods of thematic mapping of the segments and types of forest stand structures based on a method of remote sensing and GIS, segmentation method and mobile technology method in the locality of Medvedia úboč (63 ha) in Lomnistá Valley (Fig. 5, 6 ) and in the forests of fir-beech vegetation zone. Types, elements and segments of the stand structures were identified, localized and partially classify using the orthorectified multispectral aerial images (Fig. 6, 7, 8, 12) and including SPOT satellite scene. Historical aerial panchromatic images (Fig. 13) from 1949, 1971 and 1992 we used to interpret development trends of types of stand textures. Area classification was based on the method of image segmentation on images from remote sensing (Fig. 12) using the software Definiens Developer. We have located and describe in detail a total of 98 segments of the forest structure at a higher hierarchical level of 63 ha. Segment of the stand has the basic information on the stand structure and texture. At the same time, it is the basic spatial unit used to link with databases. Application of the segmentation leads to a significant rationalisation of ground-based approaches of thematic mapping and classification of stand structures. A very important aspect of the classification is considering a broader mutual spatial context, e. g. how elements and segments are structurally arranged; their size, shape, occurrence and distribution of so-called risk and critical elements of types of stand structures. We have used a detailed characteristic of the site, preservation, species, spatial and age structure of the forest segments. Information database scheme for stand segments description is presented in Figure 14. Unification of the layers of thematic 
mapping was provided with help of the network of orientation, reference and navigation points targeted by GPS visibly identified in the terrain (Fig. 2c, d, 6, 12). Research plots (Fig. 2) and their detailed biometric features identified by FieldMap technology were used as training areas for classification from remote sensing data and as calibration objects for description of the forest segments in the terrain (Table 1, Fig. 7, 8 ). Research plots were set up based on prevailing flat structural types of the territory. They are localized by GPS technology in a detail and visualized in ArcGIS environment and Stand Visualization System (SVS) (Fig. 7, 8, 11d). We have implemented also a multimedia records system of the interior and exterior for the typical structures and textures of forest stands (Fig. $9,10,11)$. The visualization system is integrated in GIS. It includes a visualization of the single trees, crown projections and dead wood in ArcGIS and SVS system (Fig. 7, 8, 11d), photography of the interior of the stand, phytocoenoses, soil probe, hemispherical photography of the crown sphere and $360^{\circ}$ panorama (Fig. $10 \mathrm{a}, \mathrm{b}$ ) and a series of video records according to the scheme in Fig. 9, the system digital photos of the interior and exterior of stand structures and images from the opposite slope (Fig. 5, 11a, b, c, 15, 16). The paper presents innovative approaches in thematic mapping and assessment of the structure and texture of forest communities in the context of the detection and assessment the condition and development of forest communities. Improved methodological approaches lie primarily in the application of a combined distance and ground-based methods and implementing of materials and technologies, notably aerial and satellite remote sensing and recent methods of image processing based on the segmentation. Practical significance and usefulness can be seen in mapping of forest habitats, the possibility of more detailed localization of the actual vegetation boundaries based on remote sensing and methods of segmentation of the assessed area. Presented approaches have been verified on a number of modelling plots and the results can be generalized to the whole range of forest communities in Slovakia.

Translated by J. Lásková 